\title{
A Comprehensive Species to Strain Taxonomic Framework for Xanthomonas
}

\author{
J. L. W. Rademaker, F. J. Louws, M. H. Schultz, U. Rossbach, L. Vauterin, J. Swings, and F. J. de Bruijn
}

First, third, fourth, and seventh authors: MSU-DOE Plant Research Laboratory; seventh author: Department of Microbiology and NSF Center for Microbial Ecology, Michigan State University, East Lansing 48824; second author: Department Plant Pathology, North Carolina State University, Raleigh 27695; fifth and sixth authors: Laboratorium voor Microbiologie; sixth author: BCCM/LMG Bacteria Collection, Rijksuniversiteit Gent, Ledeganckstraat 35, B-9000 Ghent, Belgium; and fifth author: Applied Maths BVBA, Derbystraat 331, B-9051 Ghent, Belgium.

Current address of J. L. W. Rademaker: NIZO Food Research, P.O. Box 20, 6710 BA Ede, The Netherlands.

Current address of F. J. de Bruijn: INRA-CNRS Laboratoire de Biologie Moleculaire de Relations Plantes-Microorganismes Chemin de Borde-Rouge, Auzeville BP27, 31326 Castanet-Tolosan Cedex, France.

Accepted for publication 12 May 2005.

\begin{abstract}
Rademaker, J. L. W., Louws, F. J., Schultz, M. H., Rossbach, U., Vauterin, L., Swings, J., and de Bruijn, F. J. 2005. A comprehensive species to strain taxonomic framework for Xanthomonas. Phytopathology 95:1098-1111.

A comprehensive classification framework was developed that refines the current Xanthomonas classification scheme and provides a detailed assessment of Xanthomonas diversity at the species, subspecies, pathovar, and subpathovar levels. Polymerase chain reaction (PCR) using primers targeting the conserved repetitive sequences BOX, enterobacterial repetitive intergenic consensus (ERIC), and repetitive extragenic palindromic (REP) (rep-PCR) was used to generate genomic fingerprints of 339 Xanthomonas strains comprising 80 pathovars, 20 DNA homology groups, and a Stenotrophomonas maltophilia reference strain. Computerassisted pattern analysis of the rep-PCR profiles permitted the clustering of strains into distinct groups, which correspond directly to the 20 DNA-
\end{abstract}

ABSTRACT
DNA homology groups (genospecies) previously identified. Group 9 strains (X. axonopodis) were an exception and did not cluster together into a coherent group but comprised six subgroups. Over 160 strains not previously characterized by DNA-DNA hybridization analysis, or not previously classified, were assigned to specific genospecies based on the classification framework developed. The rep-PCR delineated subspecific groups within $X$. hortorum, $X$. arboricola, $X$. axonopodis, $X$. oryzae, $X$. campestris, and $X$. translucens. Numerous taxonomic issues with regard to the diversity, similarity, redundancy, or misnaming were resolved. This classification framework will enable the rapid identification and classification of new, novel, or unknown Xanthomonas strains that are pathogenic or are otherwise associated with plants.

Additional keywords: X. albilineans, $X$. bromi, X. cassavae, X. codiaei, X. cucurbitae, X. fragariae, X. hyacinthi, X. melonis, X. pisi, X. populi, $X$. sacchari, $X$. theicola, $X$. vasicola, $X$. vesicatoria.
Members of the genus Xanthomonas have been subjected to numerous taxonomic studies $(67,69)$, using conventional biochemical tests $(23,64)$, BIOLOG $(65)$, serotyping $(1,7,41)$, pathogenicity tests (30), fatty acid analysis $(72,74,80)$, and protein profiling $(65,68,73)$. Genotypic methods have also been applied, including DNA-DNA and DNA-RNA hybridization, $(24,40,45$, $65,72)$, rRNA gene analysis $(3,6,22,39)$, plasmid profiling (28), as well as repetitive sequence-based polymerase chain reaction (repPCR)- (33-35,49), amplified fragment length polymorphism (AFLP)- $(5,26,49,52)$, and other DNA-based genomic fingerprinting methods $(6,29,56)$.

DNA-DNA homology values have provided a generally accepted means to classify bacteria $(58,78)$ and have been considered to be the "gold standard" to delimit bacterial species (59). However, pairwise DNA-DNA hybridization experiments are extremely time consuming when analyzing large collections of bacterial isolates, and thus impractical for plant pathologists. Therefore, we have examined the potential of less laborious PCR-based genomic fingerprinting techniques, such as rep-PCR $(11,75)$ to analyze genotypic relationships between xanthomonads and to cluster them into

Corresponding author: J. L. W. Rademaker; E-mail address: Rademake@dds.nl F. J. Louws; E-mail address: frank_louws@ncsu.edu

DOI: 10.1094/PHYTO-95-1098

(C) 2005 The American Phytopathological Society meaningful groups. The rep-PCR technique employs primers designed to anneal to repetitive DNA sequences distributed around the chromosome of diverse bacterial species and PCR to yield a large number of distinct amplified DNA fragments (reviews provided in literature citations 37,48,50,76 and references therein). After resolution in a gel matrix, the rep-PCRgenerated products form a complex genomic fingerprint $(11,75)$. Rep-PCR-generated genomic fingerprint patterns have proven to be highly diagnostic and amenable to differentiate closely related strains, as well as to assess the genetic diversity within a bacterial population $(4,33,34,49,55,76)$. Computer-assisted clustering of strains based on rep-PCR genomic fingerprinting correlates well with clustering based on other, more tedious genotypic analyses, such as restriction fragment length polymorphism (RFLP), pulse field gel electrophoresis $(9,27,50)$, and AFLP (49).

The most direct evidence in support of the hypothesis that PCR-based genomic fingerprinting can be used to infer genotypic or taxonomic relationships in bacteria has been derived from a detailed comparison of genotypic clusters generated by rep-PCRor AFLP-based genomic fingerprinting and pairwise DNA-DNA homology studies (49). In that study, rep-PCR- and AFLP-generated genomic fingerprints of Xanthomonas strains belonging to the 20 DNA homology groups defined by Vauterin et al. (65) and numerous pathovars were analyzed. It was found that 19 of the 20 DNA-DNA homology-derived genotypic clusters as defined by Vauterin et al. (65) correspond directly to the groups derived from genomic fingerprinting (49). Moreover, a high degree of correla- 
tion between DNA-DNA homology values and similarity values obtained among pairs of rep-PCR and AFLP genomic fingerprints was observed (49).

A comprehensive taxonomic framework is essential for developing long-term management practices such as deploying host resistance, integrating diagnostic protocols into management programs, implementing regulatory initiatives, understanding the interrelationships among pathogenic variants, and developing a stable nomenclature. There is a need not only to discern species groups, if possible $(54,65,66)$, but also to discover the diversity within each species at the pathovar and subpathovar levels, the level relevant to most applied plant pathology issues. Here we apply rep-PCR genomic fingerprinting to 339 Xanthomonas strains comprising 80 pathovars, representing 20 DNA homology groups, as well as one Stenotrophomonas maltophilia reference strain, extending our Xanthomonas classification studies (49). While all the rep-PCR-generated clusters were found to correspond well to DNA-DNA homology groups (genospecies), several DNA homology groups, including groups 2 (X. hortorum), 4 (X. arboricola), 9 (X. axonopodis), 10 (X. oryzae), 15 (X. campestris), and 16 (X. translucens), as defined by Vauterin et al. (65), were found to contain clearly defined subspecific groups. The framework developed in this study also enabled the classification of 166 xanthomonad strains not previously classified within a comprehensive framework.

\section{MATERIALS AND METHODS}

Bacterial strains. The 340 strains selected for this study are listed in Tables 1 to 3 . The strains representing 20 Xanthomonas species as defined by Vauterin et al. (65), comprising 80 pathovars of Xanthomonas and one Stenotrophomonas maltophilia reference strain were obtained from the BCCM/LMG culture collection of the Laboratorium voor Microbiologie, Universiteit Gent, Belgium. Details of each strain are available online from the BCCM/ LMG culture collection.

As indicated in Tables 1 to 3, 50 strains were analyzed (starting from cell samples) twice, seven strains three times, one strain four times, and one strain five times, including several stable colony types $(\mathrm{t} 1, \mathrm{t} 2$, and $\mathrm{t} 3)$ to compare the reproducibility of genomic fingerprint profiles. In all other respects, the nomenclature of Vauterin et al. (65) was followed.

Rep-PCR genomic fingerprinting. Genomic DNA of 400 samples was prepared using the protocol of Pitcher et al. (46) as modified (48). Rep-PCR amplification was performed on $50 \mathrm{ng}$ of purified genomic DNA in a $25-\mu$ l reaction mixture as described $(48,50)$. Using a Perkin-Elmer 480 DNA thermal cycler (PerkinElmer, Norwalk, CT), primer annealing was performed at 40, 52, or $53^{\circ} \mathrm{C}$ with repetitive extragenic palindromic (REP), enterobacterial repetitive intergenic consensus (ERIC), or BOX primers, and the reaction was overlaid with $25 \mu \mathrm{l}$ of mineral oil (Sigma M3516; Sigma Chemical, St. Louis). Alternatively, a 96 tube MJ Research PTC 100 and 200 (MJ Research, Watertown, MA), with a heated lid, were used without the application of mineral oil using and a modified annealing temperature for ERIC and BOX at $50^{\circ} \mathrm{C}(50)$. The resulting PCR products $(6 \mu \mathrm{l})$ were separated by gel electrophoresis at $4^{\circ} \mathrm{C}$ on $25-\mathrm{cm}$-long $1.5 \%$ agarose gels in $0.5 \%$ Tris-acetate-EDTA buffer at $5 \mathrm{~V} \mathrm{~cm}^{-1}$. Two independent PCR products were obtained from each DNA sample and for each primer set. Ethidium bromide-stained profiles were digitized and subjected to computer-assisted pattern analysis using GelCompar version 4.1 software (Applied Maths, Kortrijk, Belgium) (70), as previously described (48,51). The BOX-, ERIC-, and REP-PCR profiles were analyzed separately or linearly combined (BER), using the "combined gel" option of the GelCompar program.

The rep-PCR genomic fingerprints of the strains were compared using the product-moment correlation coefficient ( $r$ value) (17) applied to the densitometric curve of the gel tracks from 0.2 to $7.65 \mathrm{~kb}$ (point 30 to 390 of the resolution of 400 points) $(17,48,51)$. Cluster analysis of the pairwise similarity values was performed using UPGMA (unweighted pair group method using arithmetic averages) (57) algorithms.

\section{RESULTS AND DISCUSSION}

Rep-PCR genomic fingerprinting of Xanthomonas strains. A collection of 339 Xanthomonas and 1 Stenotrophomonas strains were characterized using BOX-, ERIC-, and REP-PCR genomic fingerprinting to generate a classification framework. These 339 strains were selected because they had been previously well-

TABLE 1. Number of genetic groups at the species level characterized by rep-PCR fingerprints ${ }^{\mathrm{a}}$

\begin{tabular}{|c|c|c|c|c|c|c|c|}
\hline Species & DNA group & BER & B & $\mathrm{E}$ & $\mathrm{R}$ & $\begin{array}{c}\text { Number of } \\
\text { strains }\end{array}$ & LMG number of analyzed strains \\
\hline$X$. fragariae & 1 & 1 & 1 & 1 & 1 & 3 & 706(2x), 708T, 710 \\
\hline$X$. hortorum & 2 & 1 & 2 & 2 & 2 & 29 & See Table 2 \\
\hline X. populi & 3 & 1 & 1 & 1 & 1 & 3 & 974, 5743T, 5753 \\
\hline$X$. arboricola & 4 & 1 & 2 & 4 & 1 & 20 & See Table 2 \\
\hline X. cassavae & 5 & 1 & 1 & 1 & 1 & 5 & $5246, \mathbf{5 2 6 4}, 5270(2 x), 670(2 x), 673 *$ \\
\hline$X$. codiaei & 6 & 1 & 1 & 1 & 1 & 2 & 8677,8678 \\
\hline X. bromi & 7 & 1 & 1 & 1 & 1 & 3 & $8267, \mathbf{8 2 6 9}(2 x), 8272(3 x)$ \\
\hline X. cucurbitae & 8 & 1 & 1 & 1 & 1 & 5 & $\mathbf{6 9 0 *}(2 x), 7480,7481,8661,8662$ \\
\hline$X$. axonopodis & 9 & 6 & 6 & 7 & 7 & 138 & See Table 3 \\
\hline$X$. oryzae & 10 & 1 & 1 & 3 & 2 & 11 & See Table 2 \\
\hline$X$. vasicola & 11 & 1 & 1 & 1 & 1 & 9 & See Table 2 \\
\hline$X$. pisi & 12 & 1 & 1 & 1 & 1 & 3 & $847,847 \mathrm{t} 1 *(2 \mathrm{x}), 847 \mathrm{t} 2$ \\
\hline$X$. melonis & 13 & 1 & 1 & 1 & 1 & 4 & $8670^{*}, 8671, \mathbf{8 6 7 2}, 8674$ \\
\hline$X$. vesicatoria & 14 & 1 & 1 & 1 & 1 & 7 & 911t1*, 916, 917, 919, 920t1, 925, 935 \\
\hline$X$. campestris & 15 & 1 & 1 & 5 & 2 & 34 & See Table 2 \\
\hline$X$. translucens & 16 & 1 & 4 & 3 & 3 & 41 & See Table 2 \\
\hline$X$. hyacinthi & 17 & 1 & 1 & 1 & 1 & 6 & $739^{*}(2 x), 740,7419, \mathbf{7 4 2}, \mathbf{8 0 4 1}, 8042$ \\
\hline$X$. theicola & 18 & 1 & 1 & 1 & 1 & 3 & $8684^{*}, 8685,8686$ \\
\hline$X$. sacchari & 19 & 1 & 1 & 1 & 1 & 2 & $471,476(2 x)$ \\
\hline$X$. albilineans & 20 & 1 & 1 & 1 & 1 & 5 & $\mathbf{4 8 2}, 487,488,490,494 \mathrm{~T}$ \\
\hline Unknown & - & 6 & 6 & 6 & 6 & 6 & $537(2 \mathrm{x}) / 541(2 \mathrm{x}) / 825 \mathrm{t} 2 / 8027 / 8285 / 896$ \\
\hline S. maltophilia & - & 1 & 1 & 1 & 1 & 1 & $957 \mathrm{~T}$ \\
\hline
\end{tabular}

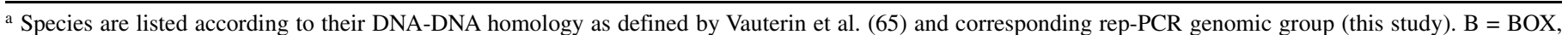
$\mathrm{E}=\mathrm{ERIC}, \mathrm{R}=\mathrm{REP}, \mathrm{BER}=\mathrm{BOX}, \mathrm{ERIC}$, and REP linearly combined. * Indicates pathovar reference strain, T-type strain, $\mathrm{t} 1$, $\mathrm{t} 2$, and $\mathrm{t} 3 \mathrm{stable}$ colony types. Bold

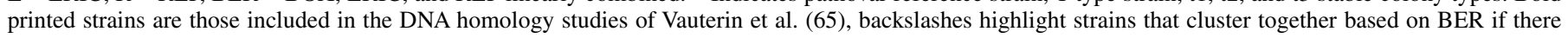
were more than one cluster in a species or pathovar. 
characterized using carbon substrate utilization (BIOLOG) (65), fatty acid methyl-esters (FAME) $(71,74,80)$, and sodium dodecyl sulfate (SDS)-polyacrylamide gel electrophoresis $(65,68)$ analyses. Moreover, 179 of these strains have been classified based on pairwise DNA-DNA homology experiments (65). For each primer set, amplification of the bacterial genomes resulted in the generation of complex fingerprint patterns. Strains analyzed more than once consistently matched each other or clustered within a group of highly similar fingerprint profiles, as a test for reproducibility of profiles generated from independent DNA extractions. For confirmation purposes and to add stability to the cluster analyses, duplicate BOX-, ERIC-, and REP-PCR genomic fingerprints were generated from these 400 DNA samples in two independent PCR reactions, resulting in a database of 2,400 rep-PCR fingerprint patterns.

Cluster analysis of rep-PCR fingerprints resolve genomic species and subspecific diversity. Cluster analysis of the linearly combined data (BER) genomic fingerprint patterns was found to group strains in units consistent with the genomic species as defined by DNA-DNA homology studies (65). Single, coherent clusters were observed for all of the 20 Xanthomonas species defined by Vauterin et al. (65) (Table 1; Fig. 1), with the exception of DNA homology group 9. The $X$. axonopodis group (group 9), represented by 38 pathovars and 138 strains in this study, consisted of six genetic clusters. The corresponding genotypic clusters are presented in abridged dendrograms (Figs. 2 to 5) and listed in
Tables 1 to 3 . The strains printed in bold were previously characterized by DNA-DNA homology (65) and formed the basis to calibrate the rep-PCR genomic fingerprinting data (49). In this study, we validate and substantially contribute to a robust taxonomic framework for most known xanthomonad groups. Over 166 strains not included in previous DNA-DNA homology work, or not previously classified within a well-defined taxonomic framework, could quickly and reliably be assigned within the framework developed (Tables 1 to 3; Figs. 1 to 5).

Diagnostic fingerprint profiles enabled clustering of Xanthomonas species and pathovars, and in addition, reproducible polymorphisms enabled differentiation of variants within species or pathovar groups. These observations extend the results found for several xanthomonad populations using rep-PCR $(4,9,33,34$, 38,42 ). The focus of this paper is on the combined BOX-, ERIC-, and REP-PCR-generated fingerprint patterns, and their relevance to the classification and identification of specific Xanthomonas strains. The use of particular rep-PCR genomic fingerprinting primers (BOX, ERIC, or REP) offered additional and unique information with regard to the homogeneity or diversity of specific species or pathovar groups compared with that of DNA homology studies. In many cases, the combined BER data grouped strains into coherent clusters consistent with the current species concept for the genus Xanthomonas, whereas the analysis based on only BOX-, ERIC-, or REP-PCR occasionally did not. In such cases, a species group may have formed two or more separate clusters

TABLE 2. Number of genetic groups characterized at the subspecific level by rep-PCR for Xanthomonas arboricola (DNA-DNA homology group 4), $X$. campestris (15), X. hortorum (2), X. oryzae (10), and X. translucens (16) and X. vasicola (11) (Figs. 2, 4, and 5) ${ }^{\mathrm{a}}$

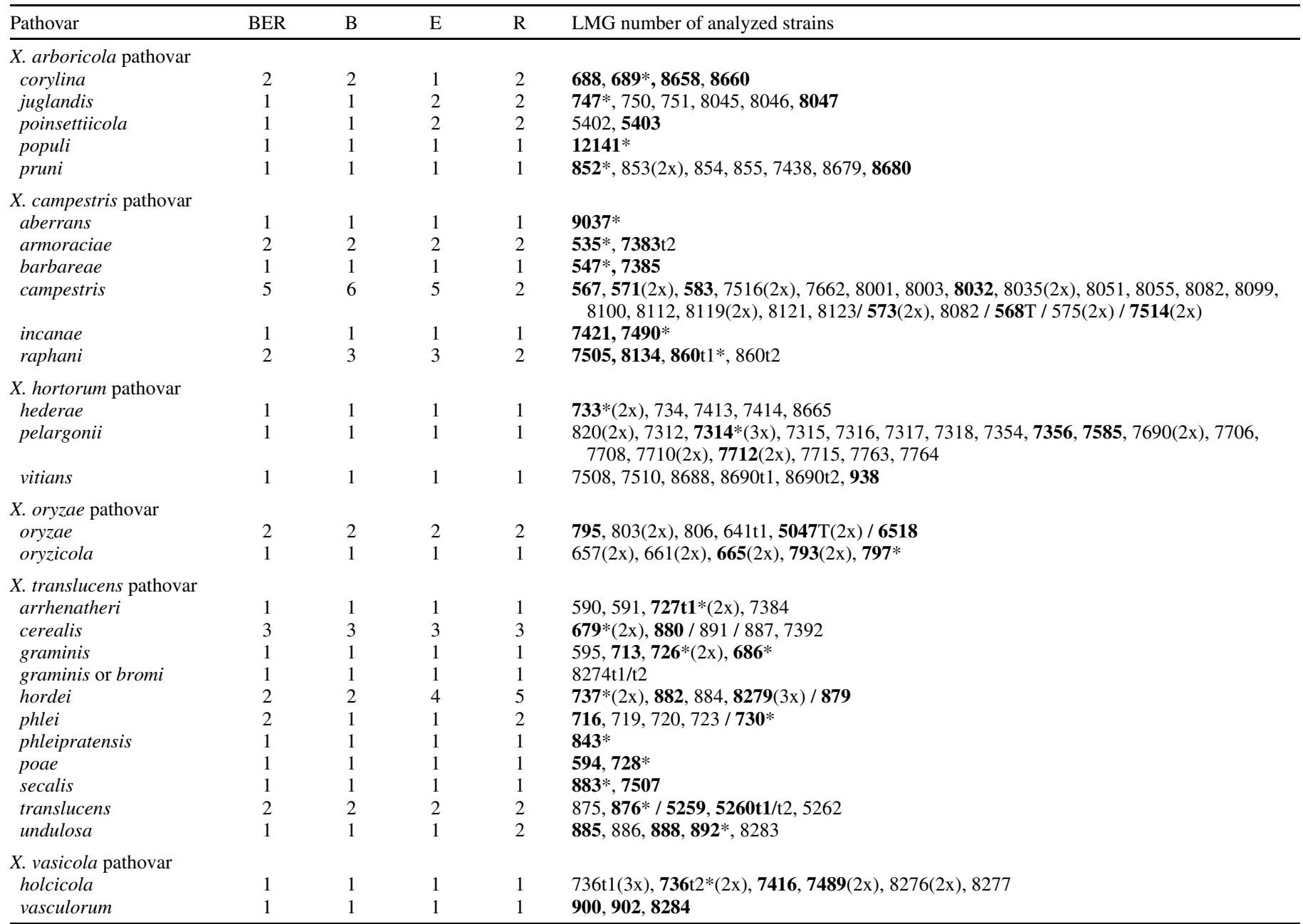

${ }^{a} \mathrm{~B}=\mathrm{BOX}, \mathrm{E}=\mathrm{ERIC}, \mathrm{R}=\mathrm{REP}, \mathrm{BER}=\mathrm{BOX}$, ERIC, and REP linearly combined. * Indicates pathovar reference strain, T-type strain, $\mathrm{t} 1, \mathrm{t} 2$, and $\mathrm{t} 3$ stable colony types. Bold printed strains are those included in the DNA homology studies of Vauterin et al. (65), backslashes highlight strains that cluster together based on BER if there were more than one cluster in a species or pathovar. 
(Table 1), although each cluster was distinctly unique compared with other species/pathovar groups. This particular data will be highlighted but figures are not provided here.

Detailed classification results from cluster analysis of repPCR fingerprints. The Xanthomonas species albilineans, bromi, cassavae, codiaei, cucurbitae, fragariae, hyacinthi, melonis, pisi, populi, sacchari, theicola, and vesicatoria were found to form distinct and coherent clusters in the UPGMA cluster analysis of separate BOX, ERIC, and REP (data not shown), and the combined BER genomic fingerprints (Table 1; Fig. 1). Our analysis showed that these species comprise strains that are highly similar to one another but have unique and therefore diagnostic fingerprint profiles that enable differentiation from all other species. Details of each Xanthomonas species will be presented in alphabetical order below.

$X$. albilineans. The five strains of $X$. albilineans formed single and coherent clusters based on BOX, ERIC, REP, and BER fingerprint profiles (Table 1; Fig. 1). The strains originating from
Mauritius, Guyana, Sri Lanka, Malawi, and Fiji, all from Saccharum officinarum, showed strain-specific polymorphisms (data not shown; online information at the BCCM/LMG bacteria culture collection database for strain-specific information with regard to geographic source, time of isolation, etc.). The rep-PCR fingerprints thus allow for classification and identification of the species as well as for strain-specific characterization. The four $X$. albilineans strains that had not been previously analyzed by DNA-DNA homology studies could be classified using the repPCR fingerprinting-based classification scheme.

$X$. arboricola. The 20 strains of $X$. arboricola yielded a single and coherent species cluster based upon analysis of BER fingerprint profiles (Table 1; Fig. 1). Pattern analysis of the genomic fingerprints resulted in pathovar-specific profiles corresponding to five pathovar groups (Table 2; Fig. 2). Strains within X. arboricola pvs. corylina, juglandis, and poinsettiicola all had BER strain-specific profiles. In contrast, $X$. arboricola pv. pruni strains $(n=7)$ exhibited BOX, ERIC, REP, and BER fingerprint profiles

TABLE 3. Number of genetic groups characterized at the subspecific level by rep-PCR for Xanthomonas axonopodis (DNA-DNA homology group 9) (Fig. 2) ${ }^{\mathrm{a}}$

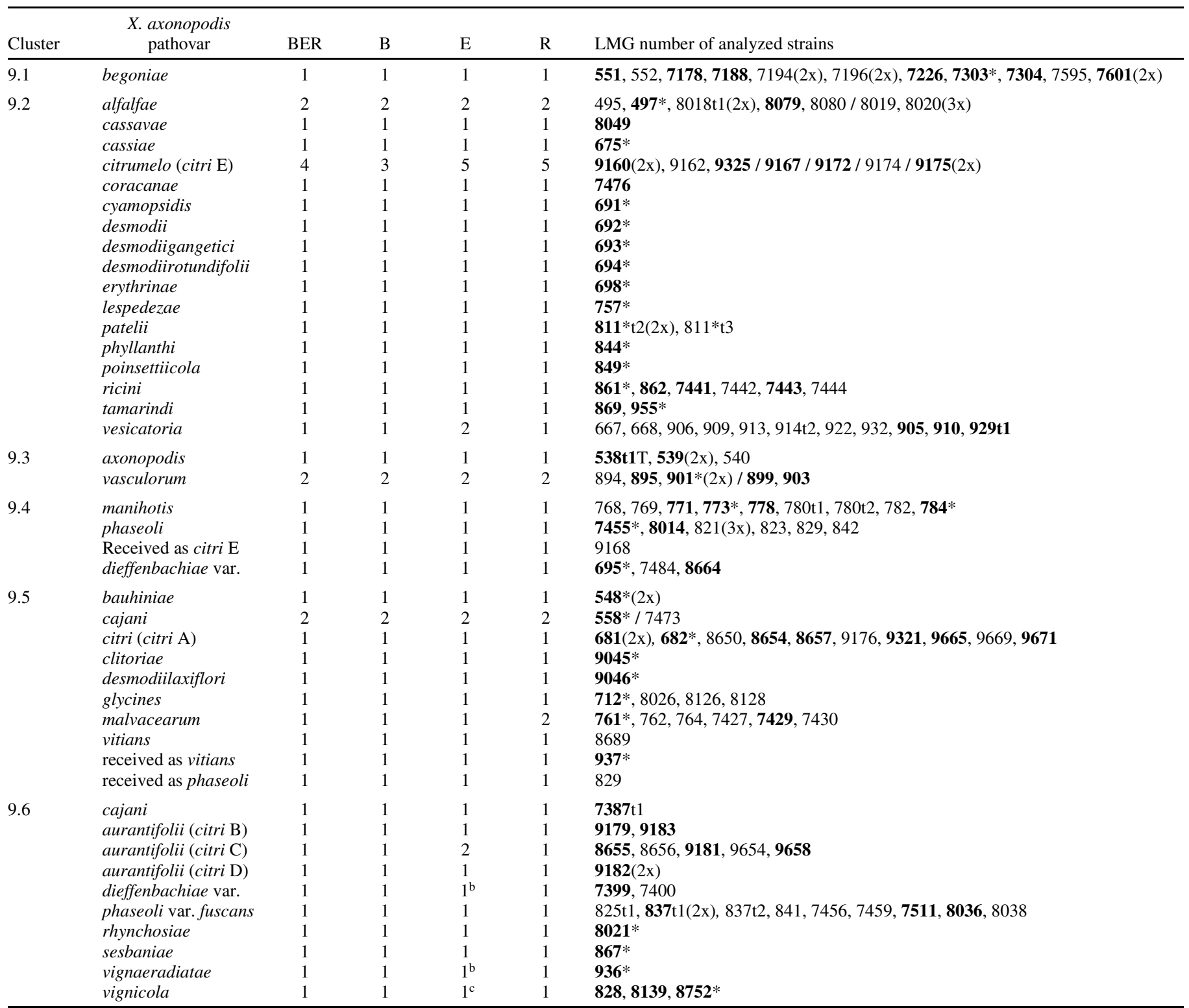

${ }^{a} \mathrm{~B}=\mathrm{BOX}, \mathrm{E}=\mathrm{ERIC}, \mathrm{R}=\mathrm{REP}, \mathrm{BER}=\mathrm{BOX}$, ERIC, and REP linearly combined. * Indicates pathovar reference strain, T-type strain, $\mathrm{t} 1, \mathrm{t} 2$, and $\mathrm{t} 3$ stable colony types. Bold printed strains are those included in the DNA homology studies of Vauterin et al. (65), backslashes highlight strains that cluster together based on BER if there were more than one cluster in a species or pathovar.

${ }^{\mathrm{b}}$ ERIC profiles were only found in cluster 9.5 .

${ }^{c}$ These profiles were found unclustered. 
highly similar to one another. A low level of diversity within this population has been confirmed, with minor polymorphisms observed using ERIC-PCR, in an analysis of 46 strains collected from six different stone fruit hosts and four countries over a 60 -year time span (36).

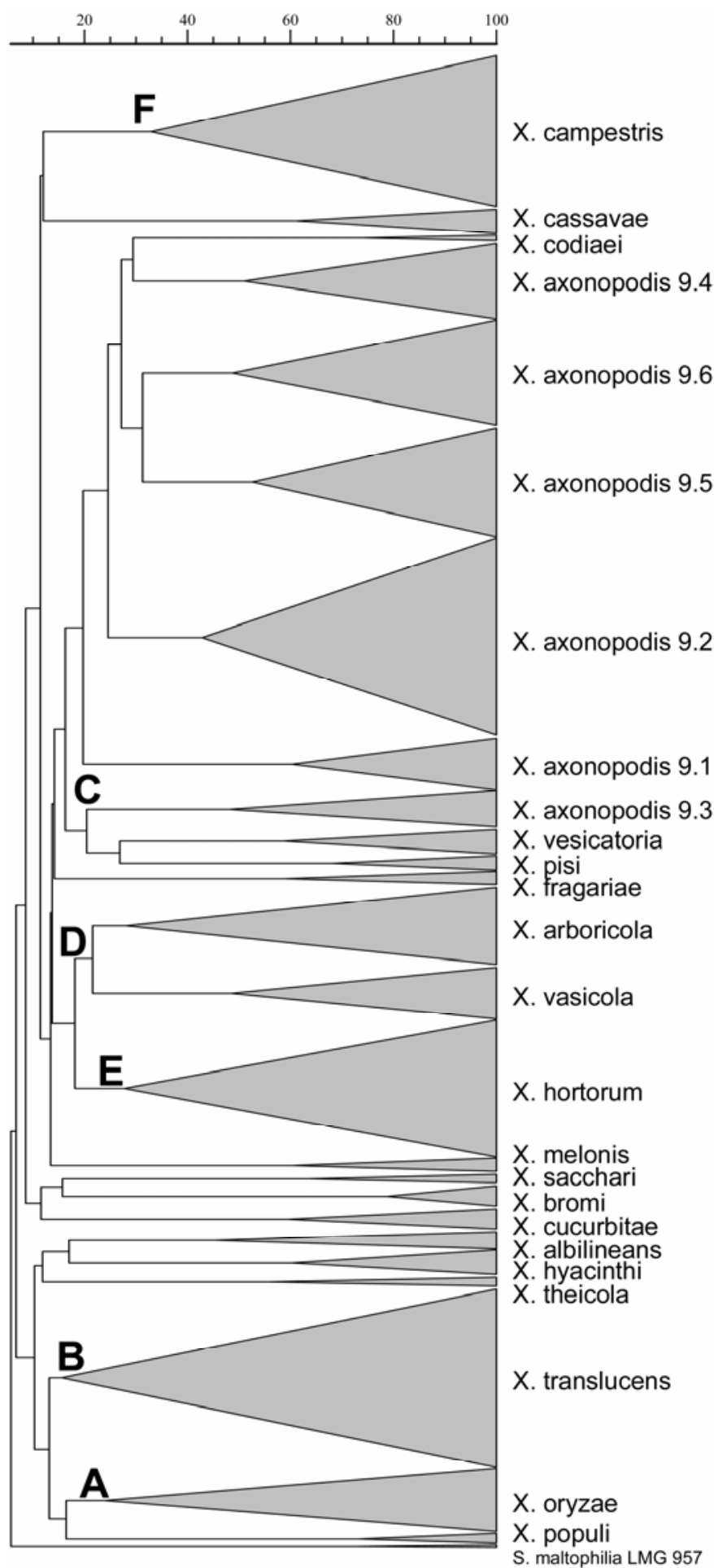

Fig. 1. Unweighted pair-group method with arithmetic average/product moment cluster analysis of linearly combined BOX, enterobacterial repetitive intergenic consensus (ERIC), and repetitive extragenic palindromic (REP) (BER) genomic fingerprint profiles of 339 Xanthomonas and 1 Stenotrophomonas strains. The analysis is based on fingerprints generated in duplicate, obtained for each of the 340 isolates using all three primer sets (2,400 fingerprints in total, including numerous independent DNA isolations from the same strains) abridged at the species level. Clusters 9.1 to 9.6 refer to six stable $X$. axonopodis subclusters. Clusters A to $\mathrm{F}$ comprise significant clusters at a subspecific level that are depicted in more detail in Figures 2 to 5.
BOX, ERIC, and REP fingerprint profiles partitioned the $X$. arboricola group into two, four, and one cluster patterns, respectively (Table 1) (data not shown). Based on the cluster analysis of the BOX-PCR genomic fingerprints, $X$. arboricola pv. populi strain LMG 12141 was found to be separated from the coherent main $X$. arboricola cluster formed by all other strains. ERIC-PCR-derived fingerprints yielded two main clusters, one formed by the $X$. arboricola pv. pruni strains and the other comprising five juglandis strains, four corylina strains, populi strain LMG 12141, and poinsettiicola strain LMG 5403 (Table 2). Additionally, $X$. arboricola pv. juglandis strain LMG 750 and $X$. arboricola pv. poinsettiicola LMG 5402 appeared as separate lineages using ERIC-PCR.

The REP-PCR genomic fingerprint profiles of $X$. arboricola pv. corylina strains, apart from LMG 8658 , were found to be highly similar and distinct from the other $X$. arboricola pathovars. The $X$. arboricola pv. juglandis REP fingerprints were divided into two clusters (Table 2), one with similarity to $X$. arboricola pv. corylina LMG 8658.

Interestingly, strain-specific ERIC fingerprints permitted clustering of the $X$. arboricola pv. corylina strains with all the $X$. arboricola pv. juglandis strains apart from LMG 750. The BOX fingerprints of the $X$. arboricola pv. corylina strains showed a high similarity, and clustered with pruni, apart from LMG 8658 which showed a unique fingerprint profile and was found to be similar to the juglandis cluster. Thus, these pathovars appear to be closely related and cross inoculation tests could be informative.

These results show that the species $X$. arboricola can be characterized and differentiated from the other Xanthomonas species by REP and BER fingerprinting. The (subspecific) grouping of the fingerprint patterns permits the placement of four $X$. arboricola pv. juglandis, one poinsettiicola, and five pruni strains, not analyzed previously by DNA-DNA homology studies, within the rep-PCR fingerprinting-based classification scheme.

$X$. axonopodis. The 138 strains of 38 pathovars of $X$. axonopodis did not cluster as a coherent group but yielded several clusters using any of the rep-PCR genomic fingerprints. Vauterin et al. (65) noted that DNA homology group 9 had the lowest DNA-DNA reassociation values and the highest standard error rate $(77 \pm 15 \%)$. Rep-PCR clarifies the genetic relatedness among the large number of strains currently classified within $X$. axonopodis. The BER fingerprint analysis generated six clusters, referred to as cluster 9.1 to 9.6 and described below (Tables 1 and

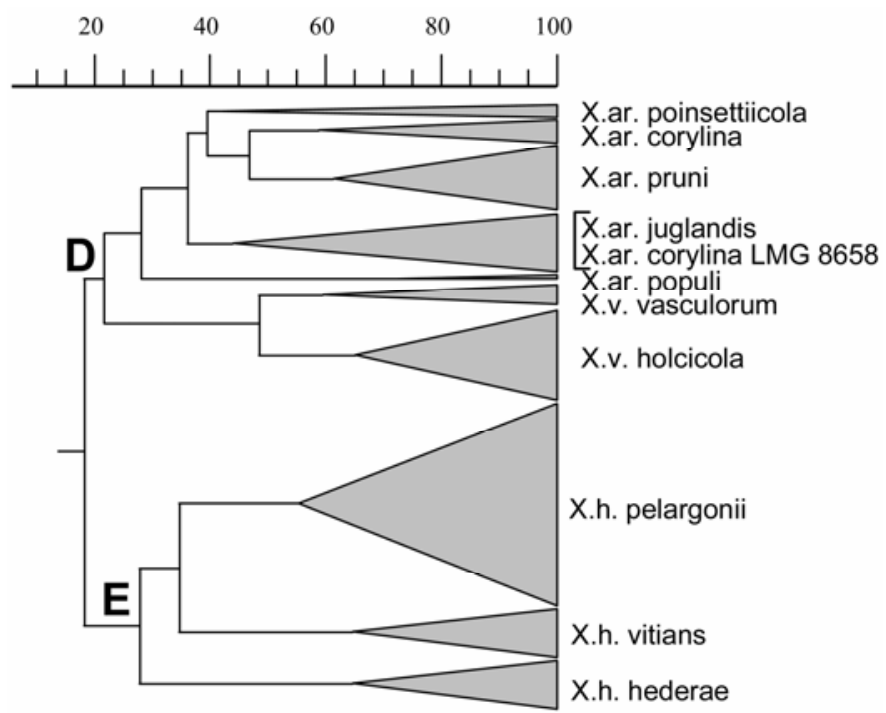

Fig. 2. Detailed parts of the unweighted pair-group method with arithmetic average/product moment cluster analysis of BER genomic fingerprint profiles of Figure 1 abridged at the subspecific level. D, Xanthomonas arboricola and vasculorum cluster; E, X. hortorum cluster. 

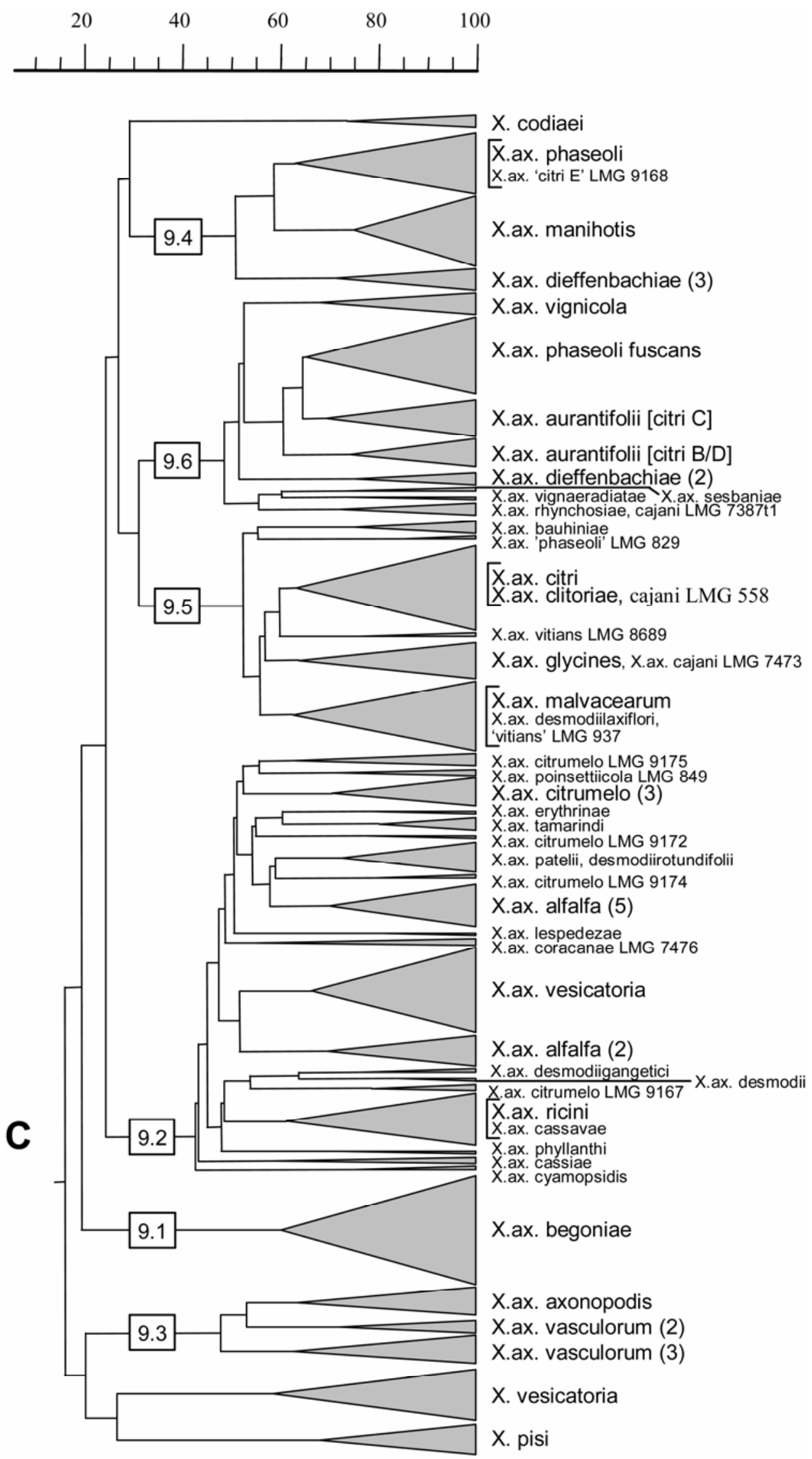

Fig. 3. Detail of the unweighted pair-group method with arithmetic average/product moment cluster analysis of BER genomic fingerprint profiles of Figure 1 abridged at the subspecific level, representing Xanthomonas axonopodis including six stable subclusters (9.1 to 9.6) and the X. vesicatoria, X. pisi, and X. codiae $i$ species clusters. Single strain entries are in small print and the strain number is indicated only when necessary for clarity. Numbers in parenthesis specify the number of strains in the genetic subgroup of the taxon. The strains are provided in Table 3. 
3; Figs. 1 and 3), two of which (9.5 and 9.6) had some overlap and may possibly be regarded as one group. X. axonopodis was divided in five separate clusters based on BOX genomic fingerprints, seven separate clusters for ERIC, and seven separate clusters based on REP genomic fingerprints (Table 1) (data not shown). Most pathovars tested could be differentiated by one or more of the rep-PCR fingerprint types. Some examples are given; furthermore, we refer to Tables 1 and 3 and Figures 1 and 3 .

Rep-PCR cluster 9.1. The 11 strains of cluster 9.1, X. axonopodis pv. begoniae, formed a single and coherent cluster based on BOX, ERIC, REP, and BER fingerprint patterns (Table 3; Figs. 1 and 3) (data not shown). The rep-PCR fingerprints thus allow for distinctive classification and identification of this pathogenic variant. Four $X$. axonopodis pv. begoniae strains, not analyzed previously by DNA-DNA homology studies, could be placed within the rep-PCR fingerprinting-based classification scheme.

rep-PCR cluster 9.2. The 45 strains of cluster 9.2 comprise the $X$. axonopodis pvs. alfalfae, cassavae, cassiae, citrumelo (citri E), coracanae, cyamopsidis, desmodii, desmodiigangetici, desmodiirotundifolii, erythrinae, lespedezae, patelii, phyllanthi, poinsettiicola, ricini, tamarindi, and vesicatoria (Table 3; Figs. 1 and 3). The 45 strains formed single and coherent clusters distinguishable from other group 9 strains based on BOX, ERIC, REP, and BER fingerprint profiles.

X. axonopodis pv. alfalfae was found to have two distinct BOX, ERIC, REP, and BER fingerprint profiles, each grouped at a high similarity. One group included strains LMG 8019 and 8020 from Japan, the other LMG 495, 497, 8018t1, 8079, and 8080 from Sudan, India, and Australia, respectively. The two lineages may correlate with their geographical origin. $X$. axonopodis pv. cassiae strain LMG 675 and X. axonopodis pv. lespedezae LMG 757 were found to have strain-specific BOX, ERIC, REP, and BER fingerprint profiles. Several different profiles were observed for $X$. axonopodis pv. citrumelo including five different ERIC-PCR profiles among seven strains (data not shown). This observation of diversity within the "citrumelo" group is in agreement with RFLP results $(15,16)$, and in contrast to FAME and protein electrophoresis that did not allow for discrimination of the strains (73). X. axonopodis pvs. coracanae, desmodii, desmodiigangetici, erythrinae, phyllanthi, and poinsettiicola were found to have pathovar-specific REP fingerprints. The six $X$. axonopodis $\mathrm{pv}$. ricini strains LMG 861, 862, 7441, 7442, 7443, and 7444, and one $X$. axonopodis pv. cassavae strain LMG 8049 formed a cluster at high similarity based on BOX, REP, and BER finger-
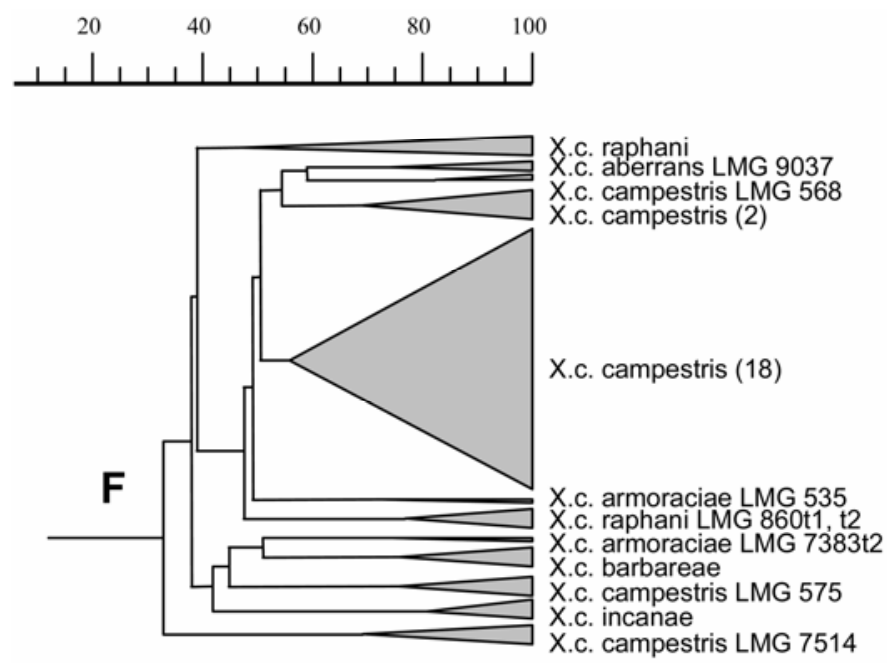

Fig. 4. Detailed parts of the unweighted pair-group method with arithmetic average/product moment cluster analysis of BER genomic fingerprint profiles of Figure 1 abridged at the subspecific level. F, Xanthomonas campestris cluster. The strains are provided in Table 2. prints. This cassavae strain showed a strain-specific ERIC fingerprint in the 9.2 cluster, separate from the subgroup of six ricini strains, allowing discrimination of the two pathovars. Cross inoculations may offer additional information regarding the pathogenicity of these strains. The BOX and BER fingerprints of cyamopsidis strain LMG 691 grouped within cluster 9.2, while the ERIC and REP profiles were found separate from this cluster. The $X$. axonopodis pv. vesicatoria strains formed a coherent group based on BOX, REP, and BER fingerprint patterns. $X$. axonopodis pv. vesicatoria LMG 910 and 929t1 exhibited strain-specific ERIC patterns that were found in cluster 9.2 but at a distance from the other $X$. axonopodis pv. vesicatoria strains. Intrapathovar diversity for this group using rep-PCR is well documented $(4,34)$. The $X$. axonopodis pvs. patelii and desmodiirotundifolii strains were found to be highly similar based on BOX, ERIC, REP, and BER genomic fingerprints. These appear to be genetically similar but were possibly given different names based on the host of isolation. Pathogenicity assays could resolve if these strains are distinctive pathovars with distinctive host ranges.

Cluster 9.2 comprises a large collection of pathovars and the rep-PCR fingerprints allowed for distinct classification and identification of many pathogenic variants. Over 15 strains, not analyzed previously by DNA-DNA homology studies, could be placed within the rep-PCR fingerprinting-based classification scheme.

Rep-PCR cluster 9.3. The eight strains of cluster 9.3 comprise three $X$. axonopodis pv. axonopodis strains including the proposed type strain for the species (LMG 538t1) and five strains received as $X$. axonopodis pv. vasculorum. The strains form a single distinct cluster based on their BOX, ERIC, REP, and BER genomic fingerprints (Table 3; Figs. 1 and 3) compared with that
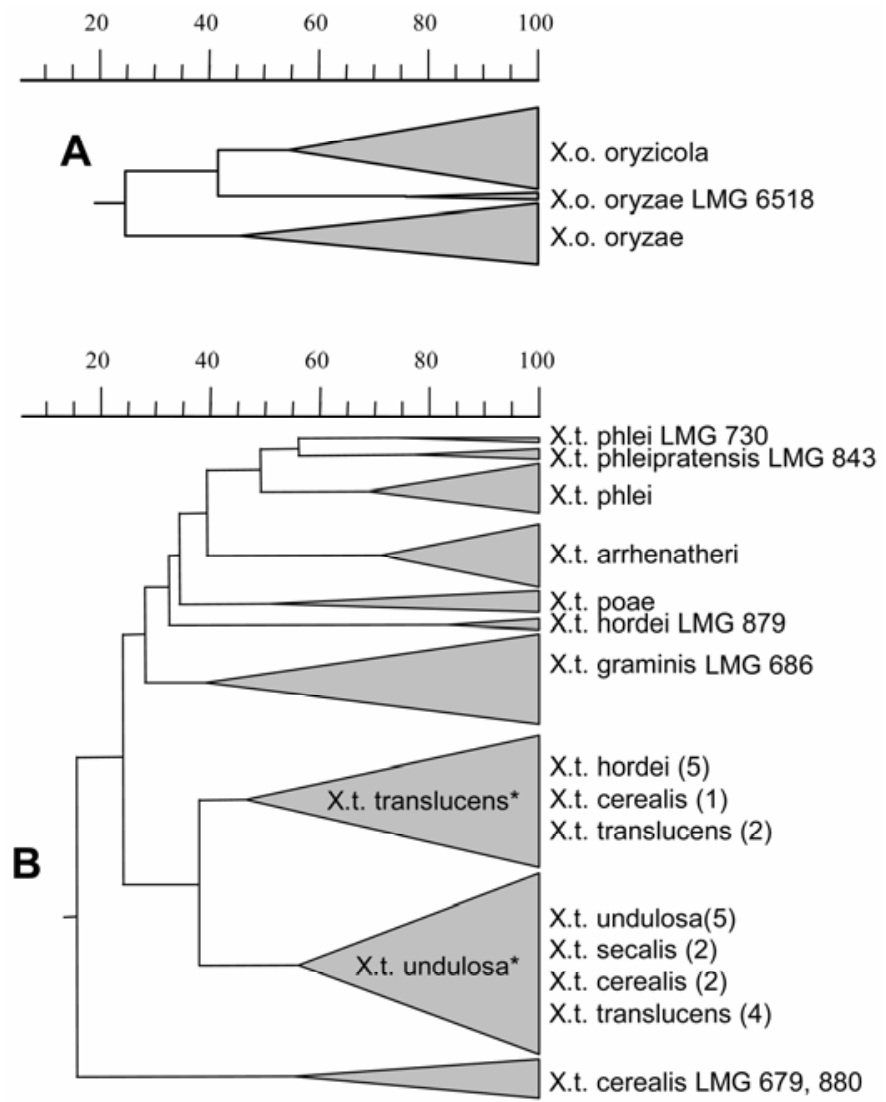

Fig. 5. Detailed illustrations of parts of the unweighted pair-group method with arithmetic average/product moment cluster analysis of BER genomic fingerprint profiles of Figure 1 abridged at a subspecific level. A, Xanthomonas oryzae cluster; B, X. translucens cluster. The * indicates groups as defined by Bragard et al. (5). The strains are provided in Table 2. 
of all other xanthomonads included in this study. This group of strains had a low correlation value with other group 9 strains. Three subclusters were observed within cluster 9.3, each consisting of highly similar strains, one containing the pathovar axonopodis (LMG 538, 539, and 540) and two subclusters of vasculorum (comprising LMG 899 and 903, and LMG 894, 895, and 901, respectively). The two vasculorum subclusters correspond to FAME clusters observed by Yang et al. (80). Moreover, the subclusters of vasculorum contained strains isolated from two different host species; Thysanolaena maxima and Saccharum officinar$u m$, suggesting a possible correlation of the subclusters with the host of origin. Pathogenicity assays could determine if strains within these subclusters warrant pathovar status. The rep-PCR fingerprints thus allow for classification and discrimination or identification of three host-specific variants in this cluster. Two strains, not analyzed previously by DNA-DNA homology studies, could be placed within the rep-PCR fingerprinting-based classification scheme.

Rep-PCR cluster 9.4. The 19 strains of cluster 9.4 comprise the $X$. axonopodis pvs. manihotis, phaseoli, and dieffenbachiae from Anturium and strain LMG 9168 (received as citri E), and form a distinct cluster based on their BOX, ERIC, REP, and BER genomic fingerprints (Table 3; Figs. 1 and 3) (data not shown). Moreover, all pathovars could be differentiated by BOX, ERIC, REP, and BER genomic fingerprints, except strain LMG 9168 which was found to cluster with the six $X$. axonopodis pv. phaseoli strains analyzed.

Fingerprints from strains received as $X$. axonopodis pv. dieffenbachiae originating from Anturium (LMG 695, 7484, and 8664) clustered in $X$. axonopodis group 9.4, while strains from dieffenbachiae (LMG 7399 and 7400) clustered in 9.6. The two clusters correspond with the two different host species suggesting a correlation, which might coincide with the two different serovars found in $X$. axonopodis pv. dieffenbachiae $(31,32)$. Depending on the host range, the strains might need reclassification, possibly into two separate pathovars or species. The rep-PCR fingerprints thus allow for classification and discrimination or identification of four host-specific variants in this cluster. Nine strains, not analyzed previously by DNA-DNA homology studies, could be placed within the rep-PCR fingerprinting-based classification scheme. The taxonomic position of strain LMG 9168 (received as citri E) appears to be of cluster 9.4 as it shows similarity with pathovars $X$. axonopodis pv. manihotis and phaseoli but may be a unique subspecific taxon and would need to be further evaluated using pathogenicity assays and more sensitive genetic analysis tools.

Rep-PCR cluster 9.5. The 28 strains of cluster 9.5 comprise $X$. axonopodis pvs. bauhiniae, cajani (LMG 588 and 7473), citri (citri A), clitoriae, desmodiilaxiflori, glycines, malvacearum, vitians, strain LMG 937 received as vitians, and strain LMG 829 received as phaseoli (Table 3; Figs. 1 and 3). The strains that constitute cluster 9.5 were found to form a distinct group based on BOX, ERIC, REP, and BER genomic fingerprints (Fig. 3). $X$. axonopodis pv. bauhiniae strain 548 (two samples) was found to yield unique ERIC, REP, and BER fingerprints compared with other cluster 9.5 strains. The three strains received as $X$. axonopodis pv. cajani, were all found in $X$. axonopodis subgroup 9.5 but appeared to be three different genomic lines, which is supported by the highly diverse FAME profiles found for these three strains (80). Two cajani strains were found in cluster 9.5, the third strain LMG $7387 \mathrm{t} 1$ clustered in 9.6. X. axonopodis pv. cajani strain LMG 588 clustered with the $10 X$. axonopodis pv. citri samples and $X$. axonopodis pv. clitoriae LMG 9045. The genomic fingerprints of $X$. axonopodis pv. cajani LMG 7473 were found to cluster with profiles obtained from four $X$. axonopodis $\mathrm{pv}$. glycines DNA samples (Fig. 3).

The citri A group had a low level of diversity and this is in close agreement with results of previous studies $(18-20,47,73)$.
The genomic fingerprints of $X$. axonopodis pv. desmodiilaxiflori strain LMG 9046 were found to have a high similarity to those of six X. axonopodis pv. malvacearum strains. Again, this strain may be misnamed or may be a distinctive pathovar to be determined through pathogenicity assays. Four $X$. axonopodis pv. malvacearum strains (LMG 762, 764, 7427, and 7430) were found to yield a REP-PCR genomic fingerprint similar to LMG 9046 but distinct from the other $X$. axonopodis pv. malvacearum strains. $X$. axonopodis pv. vitians strain LMG 8689 yielded unique fingerprints. LMG 937 was received as the pathovar reference strain of vitians but the observed fingerprints were similar to $X$. axonopodis pv. malvacearum. The equivalent strain ATTC 19320 was found to have a similar genomic fingerprint (J. L. W. Rademaker, F. J. Louws, F. J. de Bruijn, and G. H. Lacey, unpublished data). Moreover, LMG 937 was found to have no pathogenicity on lettuce (53). Apparently, some error has occurred in the past by the designation of a wrong pathovar reference strain or a mistaken strain deposited in both the ATTC and LMG collection. It has been shown in previous studies that $X$. axonopodis pv. vitians comprises highly similar strains with the exception of the aberrant pathovar reference strain LMG $937(2,53,65,68,80)$.

Strain LMG 829 was the only isolate received as $X$. axonopodis pv. phaseoli (described above in cluster 9.4) originating from Dolichos lablab, a host that belongs to the family Fabaceae like Phaseolus. According to our rep-PCR data, the isolate might need reclassification. Strain LMG 829 shows unique rep-PCR fingerprint profiles and may represent a separate genomic lineage in $X$. axonopodis cluster 9.5 , and depending on the host range, even a separate pathovar.

The rep-PCR fingerprints thus allow for classification and discrimination or identification of several pathovars and strains within this cluster. Ten strains, not analyzed previously by DNADNA homology studies, could be placed within the rep-PCR fingerprinting based classification scheme.

rep-PCR cluster 9.6. The 26 strains in cluster 9.6 comprise $X$. axonopodis pvs. cajani, aurantifolii (previously classified as citri $\mathrm{B}, \mathrm{C}$, and D), two varieties of dieffenbachiae, phaseoli var. fuscans, rhynchosiae, sesbaniae, vignaeradiatae, and vignicola (Table 3; Fig. 3). The strains that constitute cluster 9.6 were found to form a distinct group based on BOX, ERIC, REP, and BER genomic fingerprints.

$X$. axonopodis pv. aurantifolii (citri B and D) yielded highly similar ERIC and BER fingerprints allowing discrimination from any other pathovar, and $X$. axonopodis pv. aurantifolii (citri $\mathrm{C}$ ). These findings are supported by RFLP data of Hartung and Civerolo (19) and plasmid DNA fingerprints of Pruvost et al. (47), although the B, C, and D groups were found to be related enough to be classified together as $X$. axonopodis pv. aurantifolii $(12,65)$. BOX, REP, and BER fingerprint profiles from strains LMG 7399 and 7400 received as $X$. axonopodis pv. dieffenbachiae, originating from dieffenbachiae, were highly similar to one-another within cluster 9.6. Surprisingly, the ERIC fingerprints of LMG 7399 and 7400 were found to group with cluster 9.5 strains (data not shown). The $X$. axonopodis pv. dieffenbachiae isolates from Anturium were found in cluster 9.4 (described previously). $X$. axonopodis pv. phaseoli var. fuscans strains yielded a cluster of BOX, ERIC, and BER fingerprints highly similar to one another and distinctive from all other pathovars. X. axonopodis pv. sesbaniae LMG 867 was found to exhibit specific BOX, ERIC, REP, and BER fingerprints compared with other cluster 9.6 strains. $X$. axonopodis pv. vignaeradiatae yielded unique BOX, ERIC, and BER fingerprints in cluster 9.6; the ERIC patterns however clustered with strains in group 9.5. The results generated here using rep-PCR confirm and extend the findings of the homogeneity and heterogeneity of the pathovars within this group and are consistent with the data observed by Vauterin et al. (65).

The diversity and relationships as reflected by rep-PCR genomic fingerprints among $X$. axonopodis strains isolated from 
citrus hosts, i.e., citri, citrumelo, and aurantifolii, are in excellent agreement with earlier work (12,73). Three major genotypes were observed that correspond to DNA-DNA homology subgroups (73). Moreover, the level of dissimilarity between citri and aurantifolii, as part of clusters 9.5 and 9.6, respectively, suggests they may be different species. X. axonopodis pv. citrumelo is part of the somewhat more distantly related cluster 9.2 and possibly a member of a different (not yet defined) species group, again in concordance with the observations of Vauterin et al. (73).

The rep-PCR fingerprint patterns allowed for the placement of $57 X$. axonopodis strains of 22 pathogenic variants, not analyzed previously by DNA-DNA homology studies, within the rep-PCR fingerprinting-based classification scheme.

$X$. bromi. The three strains of $X$. bromi form a single, distinct and coherent species cluster based on their highly similar repPCR genomic fingerprints (Table 1; Fig. 1) (data not shown). The rep-PCR fingerprints thus allowed for classification and identification of $X$. bromi strains. Two strains, not analyzed previously by DNA-DNA homology studies, could be placed within the repPCR fingerprinting-based classification scheme.

$X$. campestris. The 34 strains of $X$. campestris form a distinct species cluster based on their BER and BOX-PCR genomic fingerprints (Table 1; Fig. 1). The REP-PCR fingerprints clustered all $X$. campestris strains, including LMG 7514, with the exception of the two X. campestris pv. incanae strains LMG 7421 and 7490, which formed a separate cluster. Based on their ERIC-PCR genomic fingerprints, the $X$. campestris strains formed a main cluster and an additional smaller cluster (data not shown). The smaller cluster comprised the fingerprints from the five strains $X$. campestris pv. barbareae LMG 547 and 7385, raphani $\mathrm{LMG}$ 7505, and incanae LMG 7421 and LMG 7490. Moreover, the ERIC fingerprint patterns of strains LMG 8134 (raphani), LMG 535 (armoraciae), and LMG 7514 (campestris) were found to be unique and separate from the two clusters. Highly remarkable was the observation that the ERIC fingerprints of the $X$. campestris pv. campestris type strain LMG 568 clustered with those of the $X$. translucens pv. graminis strains (data not shown).

All pathovars classified within the $X$. campestris species could be differentiated based on the many polymorphisms found in all the fingerprint types. Moreover, the pathovars armoraciae exhibited two, raphani three, and $X$. campestris pv. campestris several different fingerprint profiles (Table 2; Fig. 4) (data not shown). X. campestris pv. armoraciae strain LMG 535 was isolated from an Iberis sp. (Tanzania, 1954; online information at the BCCM/LMG culture collection) and had a different fingerprint profile than a second strain (LMG 7383) isolated from Armoracia lapathifolia (United States, 1939). The host range and pathogenicity of these strains has not been resolved to determine if they have a similar pathogenic phenotype or not. Misclassification of different genotypes within a single pathovar taxon has occurred previously as with $X$. campestris pv. vesicatoria (60). However, the two armoraciae strains included in this study are within the same DNA homology group 15 and they share many common rep-PCR bands and have a mutual DNA homology of $81 \%$ (B. Hoste, unpublished data). In contrast, the two genotypes previously classified as $X$. campestris pv. vesicatoria are in fact two different species, now classified within DNA homology group 9 and 14 (65), and have distinctive rep-PCR fingerprint profiles (34; this study). All three $X$. campestris pv. raphani strains were obtained from Raphanus sativus from the United States but yielded distinct fingerprints. X. campestris pv. campestris LMG 7514 was obtained from Raphanus sativus in New Zealand and yielded unique BOX and ERIC genomic fingerprints distinct from any of the strains of the $X$. campestris pathovars. However, the REP pattern of LMG 7514 clustered this strain within the major $X$. campestris pv. campestris cluster.

This analysis shows that the species $X$. campestris comprises a relatively high level of diversity but can be characterized well as a group and be differentiated from the other species by BOX and BER fingerprints, while the ERIC and REP patterns allowed further discrimination at the subspecific and strain level. Moreover, the rep-PCR fingerprint patterns allow for the placement of $16 \mathrm{X}$. campestris pv. campestris and 1 raphani strain, not analyzed previously by DNA-DNA homology studies, within the repPCR fingerprinting-based classification scheme.

$X$. cassavae. The five strains of $X$. cassavae form single, distinct and coherent species clusters based on their highly similar rep-PCR genomic fingerprints (Table 1; Fig. 1). All BOX, ERIC, REP, and BER fingerprint profiles allowed for the discrimination of $X$. cassavae from the other Xanthomonas species including the pathovar manihotis from $X$. axonopodis (previously referred to as $X$. cassavae B), another pathogen of Manihot esculenta. The repPCR fingerprints thus allow for classification and identification of the species. Three $X$. cassavae strains that had not been analyzed by DNA-DNA homology studies before could be placed in the rep-PCR fingerprinting-based classification scheme.

$X$. codiaei. The two strains of $X$. codiaei, both isolated from Codiaeum variegatum in the United States, showed similar, species-specific rep-PCR genomic fingerprint patterns (Table 1; Fig. 1). Additional strain-specific polymorphisms were observed in the BOX, ERIC, and BER fingerprint profiles of $X$. codiaei (data not shown). The rep-PCR fingerprints thus allow for classification and identification of the species as well as strainspecific characterization.

$X$. cucurbitae. The five strains of $X$. cucurbitae form one cluster distinct from all other Xanthomonas species (Table 1; Fig. 1). Strain LMG 8661 (United States, unknown host) could be differentiated by BOX, ERIC, and BER fingerprints from three New Zealand strains and one Australian strain, whereas the REP-PCR genomic fingerprint profiles of all but one $X$. cucurbitae were indistinguishable (data not shown). REP-PCR genomic fingerprints could differentiate the Australian X. cucurbitae strain LMG 7481 only. All documented X. cucurbitae strains originate from Cucurbita maxima. The rep-PCR fingerprints thus allow for classification and identification of the species. Three $X$. cucurbitae strains that had not been analyzed by DNA-DNA homology studies before could be placed in the rep-PCR fingerprinting-based classification scheme.

$X$. fragariae. The three strains of $X$. fragariae showed highly similar rep-PCR genomic fingerprints supporting previous observations $(36,42)$. The distinct and coherent clusters in the UPGMA cluster analysis of separate BOX, ERIC, REP (data not shown), and the combined BER genomic fingerprints (Table 1; Fig. 1) enabled discrimination from all other Xanthomonas species. The rep-PCR fingerprints thus allow for classification and identification of the species. One $X$. fragariae strain that had not been analyzed by DNA-DNA homology studies before could be placed in the rep-PCR fingerprinting-based classification scheme. A second group of Xanthomonas strains pathogenic on strawberries has been identified but classified within the $X$. arboricola (25) and not analyzed here.

$X$. hortorum. The 29 strains of $X$. hortorum formed a single distinct and coherent cluster based on the analysis of combined BER genomic fingerprint patterns confirming the species status of this group of strains (Table 1; Fig. 1). However, the BOX, ERIC, or REP individual fingerprints did not yield one $X$. hortorum cluster (Table 1) (data not shown). Based on BOX genomic fingerprints, two clusters were observed, one of X. hortorum pv. pelargonii and one of the pathovars hederae and vitians together. Using ERIC genomic fingerprints, pathovars hederae and pelargonii grouped together and vitians was in a separate distinct cluster. $X$. hortorum was again divided over two clusters by REP patterns, one comprising the pathovars pelargonii and vitians, the other $X$. hortorum pv. hederae.

Each pathovar group of $X$. hortorum, i.e., hederae, pelargonii, and vitians, formed single distinct and coherent clusters in the 
analyses using BOX, ERIC, REP, and the combined BER genomic fingerprints (Table 2; Fig. 2) (data not shown). Little diversity among $X$. hortorum pv. pelargonii $(n=18)$ was observed and this is supported by DNA-DNA hybridization and SDS-protein electrophoresis and FAME $(68,80)$. A similar homogeneity was found within $X$. hortorum pvs. hederae $(n=5)$ and vitians $(n=6)$. Polymorphisms in ERIC fingerprints differentiated three groups among the five strains of $X$. hortorum pv. vitians, all from Lactuca sativa. The strains of the three groups were as follows: (i) LMG 8688 (New Zealand); (ii) LMG 8690 (New Zealand) and 938 (Zimbabwe); and (iii) LMG 7510 (Australia) and 7508 (New Zealand). Our analysis shows that $X$. hortorum can be characterized well and be differentiated from the other species by repPCR fingerprints, and pathovar-specific profiles were observed. Four $X$. hortorum pv. hederae, fourteen pelargonii, and five vitians strains that had not been analyzed by DNA-DNA homology studies before could be placed in the rep-PCR fingerprintingbased classification scheme with the added resolution at the subspecific and pathovar levels.

$X$. hyacinthi. Rep-PCR genomic fingerprints revealed a high genotypic similarity among the six strains of $X$. hyacinthi. These strains form a single, distinct and coherent species cluster (Table 1; Fig. 1). The highly similar rep-PCR genomic fingerprints allowed discrimination from all other Xanthomonas species. Four $X$. hyacinthi strains that had not been analyzed by DNA-DNA homology studies before could be placed in the rep-PCR fingerprinting-based classification scheme.

$X$. melonis. The four strains of X. melonis from Cucumis melo, all from Brazil, form single, distinct and coherent clusters in the analyses using BOX, ERIC, REP, and the combined BER genomic fingerprint profiles (Table 1; Fig. 1) (data not shown). Additionally, the $X$. melonis strains each exhibited strain-specific ERIC fingerprints (data not shown). The rep-PCR fingerprints thus allow for classification and identification of the species as well as for strain-specific characterization. Three $X$. melonis strains that had not been analyzed by DNA-DNA homology studies before could be placed in the rep-PCR fingerprintingbased classification scheme.

$X$. oryzae. The 11 strains of $X$. oryzae revealed a single species cluster after the analysis of BOX and BER fingerprint profiles (Table 1; Fig. 1) (data not shown) that was distinct from all other Xanthomonas species, confirming their placement within a single species (62). X. oryzae strains formed two major clusters according to their pathogenic phenotype and consistent with their pathovar status in X. oryzae pvs. oryzae and oryzicola (Table 2; Fig. 5), as previously observed (33). The $X$. oryzae pvs. oryzae and oryzicola exhibited very distinctive ERIC- and REP-PCR genomic fingerprint profiles (Table 1) (data not shown), which was surprising, since these strains have been reported to have a DNADNA homology of $91 \pm 7 \%$ (65). This could suggest that chromosomal rearrangements might have occurred that changed the chromosomal organization of ERIC and REP elements but did not affect the BOX patterns. The changes in the chromosomal organization may have enabled the two pathovars to occupy different niches, expressed by distinctive pathogenicity types on rice.

Based on BOX fingerprints, five $X$. oryzae genotype groups were observed, including strains LMG 665, 6518, 793, all with distinctive profiles, and the remainder in the two groups comprising the two pathovars.

Interestingly, strain LMG 6518 received as, and according to DNA-DNA homology data (62), $X$. oryzae pv. oryzae had an ERIC and REP profile that was separate from any of the other $X$. oryzae strains but was confirmed as $X$. oryzae by BOX-PCR fingerprint profiles. This strain (IRN 325) incited typical bacterial blight symptoms, a unique protein profile, and formed a group at the edge of the oryzae phenon based on 133 phenotypic features in a study of 35 oryzae and 14 oryzicola strains (10).
The rep-PCR fingerprints thus allowed for classification and identification of the species $X$. oryzae by BOX and BER fingerprints as well as for subspecific characterization by REP and ERIC profiles. The fingerprint profiles allowed for the placement of three $X$. oryzae and two oryzicola strains, not analyzed previously by DNA-DNA homology studies, within the rep-PCR fingerprinting-based classification scheme.

X. pisi. X. pisi was represented by four independent DNA samples of one strain that showed distinct rep-PCR genomic fingerprints allowing discrimination from any other species. Moreover, the rep-PCR genomic fingerprints were highly reproducible.

$X$. populi, X. sacchari, and $X$. theicola. The three strains of $X$. populi, two strains of $X$. sacchari, and three strains of $X$. theicola, each yielded single, distinct and coherent clusters allowing discrimination among these and the other Xanthomonas species. The rep-PCR fingerprints thus allowed for classification and identification of these species.

$X$. translucens. The 41 strains of $X$. translucens comprised the pathovars arrhenatheri, cerealis, graminis, hordei, phlei, phleipratensis, poae, secalis, translucens, undulosa, and the strains LMG 686 and LMG 8274t1/t2 received as X. axonopodis pv. coracanae and "graminis or bromi," respectively, and formed one cluster based on the BER profiles (Table 1; Fig. 1). Two "cerealis" strains LMG 679 and 880 (three samples) formed a subgroup within this cluster at a lower similarity (Fig. 5). The lower similarity of strains LMG 679 and 880 with the other $X$. translucens is supported by DNA-DNA reassociation results. The DNA-DNA homology between the two is $82 \%$, whereas the DNA homology between LMG 679 and any of seven other $X$. translucens strains is significantly lower, ranging from 58 to $76 \%$ with an average of $65 \%$ (B. Hoste, personal communication).

$X$. translucens was distributed over four groups based on their BOX-PCR genomic fingerprints: one of pathovar graminis; one cluster of the two cerealis strains LMG 679 and 880; one cluster with phlei, phleipratensis, poa, and arrhenatheri; and one comprising secalis, undulosa, translucens, cerealis, and hordei (Table 1) (data not shown). The ERIC genomic fingerprints of $X$. translucens were separated over a graminis and a phlei cluster and a third group with the remaining eight pathovars, surprisingly including LMG 679 and 880. REP-PCR genomic fingerprints of $X$. translucens clustered all strains into two related groups, one with the majority of strains analyzed and a second that included undulosa, hordei, and cerealis strains, and a third separate LMG 679 and 880 cluster.

$X$. translucens pvs. arrhenatheri, graminis, phlei, phleipratensis, and poae were found to form distinct and coherent clusters separate from the other pathovars by their BOX, ERIC, REP, and combined BER genomic fingerprints (Table 2; Fig. 5) (data not shown). Interestingly, phleipratensis LMG 843 was more similar to phlei LMG 730 based on the BER fingerprints than between either one of them and the other phlei fingerprints (data not shown).

The pathovars cerealis, hordei, and translucens were found distributed over two distinct clusters. Based on the use of many matching reference strains, it was found that this distribution corresponds to the two groups defined by Bragard et al. (5). The isolates LMG $8274 \mathrm{t} 1$ and t2 from Festuca arundinacea (New Zealand) received as pathovar graminis were found atypical in FAME analysis (80; LMG culture collection information 1992). The BOX and BER genomic fingerprints of these strains did show similarity to $X$. translucens pv. graminis, while the ERIC patterns showed similarity to $X$. oryzae pv. oryzae and LMG 6518 (Table $2 ; X$. oryzae). The REP fingerprints of these strains showed similarity to $X$. translucens pv. arrhenatheri. Based on rep-PCR data, LMG 8274t 1 and $\mathrm{t} 2$ are apparently part of the $X$. translucens species; however, a host range study of this pathogen might lead 
to a more specific classification, maybe the circumscription of a new pathovar.

Strain LMG 686, received as $X$. axonopodis pv. coracanae, was found only remotely related to $X$. axonopodis pv. coracanae strain LMG 7476 based on FAME analysis (80) and rep-PCR genomic fingerprinting (this study). The strain LMG 686 appears to be closely related to $X$. translucens pv. graminis since their BOX, ERIC, REP, and BER genomic fingerprints are highly similar. However, only pathogenicity tests can determine if these are the same pathovar but currently given different names. Strain LMG 7476 clustered in $X$. axonopodis group 9.2 and is likely correctly classified as $X$. axonopodis pv. coracanae. Moreover, strains LMG 8274t1/t2 and LMG 686 appear to have amplified small subunit ribosomal RNA gene digests typical for $X$. translucens (J. L. W. Rademaker, M. H. Schultz, and F. J. de Bruijn, unpublished data). The strains are likely to be members of $X$. translucens, LMG 686 as X. translucens pv. graminis and LMG $8274 \mathrm{t} 1 / \mathrm{t} 2$ possibly as a new pathovar. These findings are well supported by the results described by Bragard et al. (5).

Our analysis shows that the species $X$. translucens can be characterized well and be differentiated from the other species by BER fingerprints (Table 1; Fig. 1). The separate rep-PCR patterns allow further subspecific discrimination (Table 1; Fig. 5) (data not shown), highlighting the high diagnostic value of the fingerprint patterns. Moreover, the rep-PCR fingerprint patterns allow for the placement of three $X$. translucens pv. arrhenatheri, three cerealis, two graminis, one hordei, three phlei, two translucens, and two undulosa strains, not analyzed previously by DNA-DNA homology studies, within the rep-PCR fingerprinting-based classification scheme.

X. vasicola. The nine strains of $X$. vasicola formed a distinct coherent species cluster (Table 1; Fig. 1) in which two pathovar subclusters, the vasculorum and holcicola groups, could be distinguished based on their rep-PCR genomic fingerprint profiles (Table 2; Fig. 2). Additionally, three X. vasicola pv. vasculorum strains could be differentiated according to their fingerprints, two strains (LMG 900 and 902) from Saccharum officinarum (Malagasy Republic and South Africa) and a third strain LMG 8284 from Zea mays (South Africa). The five X. vasicola pv. holcicola strains from Sorghum (New Zealand) were found to be genetically similar to one another based on their fingerprint profiles (data not shown). Three $X$. vasicola pv. holcicola strains that had not been analyzed previously by DNA-DNA homology studies could be placed in the rep-PCR fingerprinting-based classification scheme.

$X$. vesicatoria. The seven strains of $X$. vesicatoria form distinct and coherent clusters based on their rep-PCR genomic fingerprints that allowed discrimination from all other Xanthomonas species including $X$. axonopodis pv. vesicatoria (Table 1; Fig. 1). Moreover, the rep-PCR fingerprint patterns allow for the placement of six $X$. vesicatoria strains, not analyzed previously by DNA-DNA homology studies, within the rep-PCR fingerprintingbased classification scheme.

Stenotrophomonas maltophilia. The fingerprint profile of the Stenotrophomonas maltophilia strain was found separate and with a very low similarity with all other strains (Table 1; Fig. 1). These results are supported by findings of Palleroni and Bradbury (44) and Hauben et al. $(21,22)$.

Nonclassified xanthomonads. The strains LMG 537, 541, $825 \mathrm{t} 2,8027,8285$, and 896 were received as specifically named Xanthomonas pathovars. However, these strains did not cluster with those specific pathovars based on their rep-PCR genomic fingerprints and appear to be misidentified. The strains appear to be unrelated to any other Xanthomonas pathovar or strain tested, supporting previous results. They were misidentified or atypical based on FAME analysis (80; LMG website information). These strains had not been selected for previous DNA-DNA homology studies (65). Moreover, amplified small subunit ribosomal RNA gene digests of the strains were found atypical for Xanthomonas (J. L. W. Rademaker, M. H. Schultz, and F. J. de Bruijn, unpublished data) and therefore excluded from Figure 1.

Xanthomonas taxonomy. The rep-PCR classification framework developed in this study supports the taxonomic framework developed by Vauterin et al. (65), which in turn was developed based on a polyphasic analysis of large populations of Xanthomonas strains (66). The rep-PCR offered more resolution than those defined by DNA homology experiments and clearly defined subspecific groups within $X$. hortorum, $X$. arboricola, $X$. axonopodis, $X$. oryzae, $X$. campestris, and $X$. translucens, as discussed in detail previously. DNA homology group 9 (sensu Vauterin et al. [65]) is of particular interest and tends to be one of the main points of discussion amongst Xanthomonas taxonomists $(54,66$, 81). Group 9 is a complex group of host-adapted strains that was classified as $X$. axonopodis with many pathovars (65). Using repPCR, this heterogeneous collection of strains constitute six distinct genomic groups labeled here as clusters 9.1 to 9.6. The ability to reliably distinguish these groups suggests these groups may constitute different species groups. Additional research using DNA homology studies and other taxonomic tools may elevate members of these groups to species status. In our study, we have documented strains that should be considered within each group if such groups are to be properly classified and named as species. Ideally, all strains within the groups should be elevated simultaneously rather than piecemeal.

This paper also highlights some unique occurrences of strains that appear to have undergone convergent evolution, and acquired pathogenicity for a common host, and divergent evolution, where closely related organisms have distinctive pathogenicity profiles. Likewise, we discovered strains that had different names but appear to be genetically similar, strains with similar names but are genetically very distinct, and we have discovered what appear to be misnamed or mislabeled strains. For example, a well documented case of genetically distinct strains able to incite a similar disease are xanthomonads pathogenic on tomato $(34,60)$. X. axonopodis pv. vesicatoria clusters with group 9.2 strains, whereas $X$. vesicatoria has a completely different rep-PCR profile. A second well documented example $(8,38)$ are strains pathogenic for Phaseolus vulgaris. X. axonopodis pv. phaseoli and X. axonopodis pv. phaseoli var. fuscans are clearly in two very distinctive genetic groups, group 9.4 and 9.6, respectively. There were numerous occurrences where strains were given different names, based on the host from which they were isolated, but they appear to be genetically very similar (e.g., desmodiilaxiflori and malvacearum strains; patelli and desmodiirotundifollii strains; vignaeradiatae and sesbaniae strains; and numerous cases within the translucens group). However, with a solid systematic framework, the proper experiments can be done to help discern differences, if they exist. Cross-pathogenicity tests may help resolve if such strains are truly pathogenic variants or the same organisms able to incite disease on multiple hosts. In contrast, strains (for example) named dieffenbachiae clearly belong to at least two genetically distinct groups, group 9.4 and group 9.6, and these two groups likely represent two species.

Mislabeled or misnamed strains include the "unknown" strains received as named pathovars but which did not cluster with any known xanthomonads, and strains such as X. vitians LMG 8686, the "type" strain that is neither representative of most strains pathogenic for lettuce and is itself not pathogenic (53).

Rep-PCR as a tool in bacterial taxonomy. DNA homology studies $(58,78)$ and more recently sequencing of ribosomal DNA $(59,79)$ form the basis to differentiate and classify bacteria at the species level. However, nucleic hybridization and sequencing protocols are not routinely accessible to the practical bacteriologist for typing unknown strains and comparing them to the known "reference" or type strains. Moreover, 16S RNA sequence analysis of xanthomonads shows limited variability (22) and does 
not have sufficient resolution to differentiate all species nor each host-adapted strain within a species. Likewise, DNA homology studies, as highlighted by Vauterin et al. (65), are not easy to perform and need to be performed pairwise for all strains, an impractical approach for large collections of bacteria. Palleroni (43) stressed the need "for a rapid genotyping approach to bridge the gap between the solid systematics of type strains and the everyday need for comparison of new isolates and old reference strains."

The observed high correlation between DNA-DNA homology studies and rep-PCR and AFLP genomic fingerprint analyses suggests that genomic fingerprint methods can function as core techniques in polyphasic taxonomy regardless of the statistical model employed (49) and such protocols can be considered a core tool in bacterial systematics (58). The application of rep-PCR genomic fingerprinting as a sole tool for defining a species is not advisable. The power of rep-PCR genomic fingerprinting in bacterial taxonomy lies in swift and cost effective placement of (large) collections of strains in a classification framework based on additional solid systematics such as DNA-DNA homology.

In our experience, development of a classification framework using rep-PCR requires some a priori knowledge about the identity of the unknown bacteria. Classification of unrelated strains by rep-PCR would benefit from prescreening or confirmation by other analyses with a lower taxonomic resolution like amplified ribosomal DNA restriction analysis (ARDRA) (77), FAME (69), BIOLOG (65), or $16 \mathrm{~S}$ rDNA sequence analysis. The rep-PCR generates complex genomic fingerprint profiles. Thus, we have observed co-migrating but presumably nonanalagous DNA bands could result in strains from a different genus to cluster within an Xanthomonas cluster as opposed to being a distinct outlier when subjected to pattern analysis. Once the genus is known, then the unknown can be analyzed within the context of a genus-specific framework as done here. Perhaps, strains of other bacterial populations may have more diversity and a genus-specific framework or database may be too complex requiring the development of a database at the species level.

In this study, we had previous knowledge about the taxonomic framework of the genus Xanthomonas and this helped corroborate the rep-PCR data and enabled detailed assessment of genetic diversity or similarity amongst strains with resolution at the subspecific, pathovar, and even strain level. Once a classification framework is generated and a rep-PCR database developed, the discovery of a strain with a new rep-PCR genomic fingerprint could enable rapid classification of that strain when compared with a large collection of strains previously characterized (48) or through the use of a neural network based on a large database (63). This approach enabled us to identify or classify unknown strains. For example, novel xanthomonad strains were isolated from tomato in Costa Rica (4) and from tomato transplants in greenhouses in North America (F. J. Louws, unpublished data) that had a near-identical fingerprint profile as the type strain for X. gardneri (J. L. W. Rademaker, F. J. Louws, and F. J. de Bruijn, unpublished data), a pathogen that had not been reported since 1957 (61). More recently, the classification scheme developed in this study enabled the rapid and precise classification of strains associated with the recent emerging disease of bacterial blight of onions (14). The strains were found to belong to rep-PCR cluster 9.2 and were classified as $X$. axonopodis pv. alii. Of particular interest, the "alii" strains had fingerprint profiles very similar to $X$. axonopodis pv. alfalfa and $X$. axonopodis pv. citrumelo leading to a hypothesis-driven study concerning the host specificity of these pathovars (13).

In this study, over 160 strains not included in previous DNADNA homology studies have been reliably classified within a comprehensive taxonomic framework for the genus Xanthomonas. Twenty distinct species, previously described (65), could be circumscribed using rep-PCR and several additional rep-PCR groups were delineated, suggesting further characterization and naming of species will be productive future research, particularly within the DNA homology group 9. Numerous taxonomic issues with regard to the diversity, similarity, redundancy, or misnaming of strains were resolved. A comprehensive framework has and will enable the rapid identification and classification of new, novel, or unknown strains that are plant pathogens, epiphytes, or saprophytes.

\section{ACKNOWLEDGMENTS}

The development of the rep-PCR genomic fingerprinting method for the analysis of plant-associated and soil microbes has been supported by the DOE (DE FG 0290ER20021), the NSF Center for Microbial Ecology (DIR 8809640), Heinz Inc., Rogers Seeds (Syngenta Seeds), Procter \& Gamble and the Consortium for Plant Biotechnology Research (DE FC05-92OR22072), and the States of Michigan and North Carolina. We thank M. Schneider, J. Wallace, R. Jaros (MSU), L. Hauben, S. VanEygen (RUG Belgium), and J. Lupski (Baylor College of Medicine, Houston) for technical support and many useful discussions on rep-PCR.

\section{LITERATURE CITED}

1. Alvarez, A. M., Benedict, A. A., Mizumoto, C. Y., Hunter, J. E., and Gabriel, D. W. 1994. Serological, pathological, and genetic diversity among strains of Xanthomonas campestris infecting crucifers. Phytopathology 84:1449-1457.

2. Barak, J. D., and Gilbertson, R. L. 2003. Genetic diversity of Xanthomonas campestris pv. vitians, the causal agent of bacterial leafspot of lettuce. Phytopathology 93:596-603.

3. Berthier, Y., Verdier, V., Guesdon, J. L., Chevrier, D., Denis, J. B., Decoux, G., and Lemattre, M. 1993. Characterization of Xanthomonas campestris pathovars by ribosomal-RNA gene restriction patterns. Appl. Environ. Microbiol. 59:851-859.

4. Bouzar, H., Jones, J. B., Stall, R. E., Louws, F. J., Schneider, M., Rademaker, J. L. W., de Bruijn, F. J., and Jackson, L. E. 1999. Multiphasic analysis of xanthomonads causing bacterial spot disease on tomato and pepper in the Caribbean and Central America: Evidence for common lineages within and between countries. Phytopathology 89:328-335.

5. Bragard, C., Singer, E., Alizadeh, A., Vauterin, L., Maraite, H., and Swings, J. 1997. Xanthomonas translucens from small grains: Diversity and phytopathological relevance. Phytopathology 87:1111-1117.

6. Bragard, C., Verdier, V., and Maraite, H. 1995. Genetic diversity among Xanthomonas campestris strains pathogenic for small grains. Appl. Environ. Microbiol. 61:1020-1026.

7. Bragard, C., and Verhoyen, M. 1993. Monoclonal-antibodies specific for Xanthomonas campestris bacteria pathogenic on wheat and other small grains, in comparison with polyclonal antisera. Phytopathol. Z. 139:217228.

8. Chan, J. W. Y. F., and Goodwin, P. H. 1999. Differentiation of Xanthomonas campestris pv. phaseoli from Xanthomonas campestris pv. phaseoli var. fuscans by PFGE and RFLP. Eur. J. Plant Pathol. 105:867-878.

9. Cruz, C. M. V., Ardales, E. Y., Skinner, D. Z., Talag, J., Nelson, R. J., Louws, F. J., Leung, H., Mew, T. W., and Leach, J. E. 1996. Measurement of haplotypic variation in Xanthomonas oryzae within a single field by rep-PCR and RFLP analyses. Phytopathology 86:1352-1359.

10. Cruz, C. M. V., Gossele, F., Kersters, K., Segers, P., Vandenmooter, M., Swings, J., and Deley, J. 1984. Differentiation between Xanthomonas campestris pv. oryzae, Xanthomonas campestris pv. oryzicola and the bacterial brown blotch pathogen on rice by numerical analysis of phenotypic features and protein gel electrophoregrams. J. Gen. Microbiol. 130:2983-2999.

11. de Bruijn, F. J. 1992. Use of repetitive (repetitive extragenic palindromic and enterobacterial repetitive intergenic consensus) sequences and the polymerase chain reaction to fingerprint the genomes of Rhizobium meliloti isolates and other soil bacteria. Appl. Environ. Microbiol. 58:2180-2187

12. Gabriel, D. W., Kingsley, M. T., Hunter, J. E., and Gottwald, T. 1989. Reinstatement of Xanthomonas citri (Ex Hasse) and Xanthomonas phaseoli (Ex Smith) to species and reclassification of all Xanthomonas campestris pv. citri strains. Int. J. Syst. Bacteriol. 39:14-22.

13. Gent, D. H., Al-Saadi, A., Gabriel, D. W., Louws, F. J., Ishimaru, C. A., and Schwartz, H. F. 2005. Pathogenic and genetic relatedness among Xanthomonas axonopodis pv. allii and other pathovars of X. axonopodis. Phytopathology 95:918-925.

14. Gent, D. H., Schwartz, H. F., Ishimaru, C. A., Louws, F. J., Cramer, R. A., and Lawrence, C. B. 2004. Polyphasic characterization of Xanthomonas strains from onion. Phytopathology 94:184-195. 
15. Graham, J. H., and Gottwald, T. R. 1991. Research perspectives on eradication of citrus bacterial diseases in Florida. Plant Dis. 75:11931200.

16. Graham, J. H., Hartung, J. S., Stall, R. E., and Chase, A. R. 1990. Pathological, restriction fragment length polymorphism, and fatty-acid profile relationships between Xanthomonas campestris from citrus and noncitrus hosts. Phytopathology 80:829-836.

17. Hane, B. G., Jager, K., and Drexler, H. G. 1993. The Pearson productmoment correlation-coefficient is better suited for identification of DNA fingerprint profiles than band matching algorithms. Electrophoresis. 14:967-972.

18. Hartung, J. S., and Civerolo, E. L. 1987. Genomic fingerprints of Xanthomonas campestris pv. citri strains from Asia, South-America, and Florida. Phytopathology 77:282-285.

19. Hartung, J. S., and Civerolo, E. L. 1989. Restriction fragment length polymorphisms distinguish Xanthomonas campestris strains isolated from Florida citrus nurseries from $X$. c. pv. citri. Phytopathology 79:793-799.

20. Hartung, J. S., Daniel, J. F., and Pruvost, O. P. 1993. Detection of Xanthomonas campestris pv. citri by the polymerase chain reaction method. Appl. Environ. Microbiol. 59:1143-1148.

21. Hauben, L., Vauterin, L., Moore, E. R. B., Hoste, B., and Swings, J. 1999. Genomic diversity of the genus Stenotrophomonas. Int. J. Syst. Bacteriol. 49:1749-1760.

22. Hauben, L., Vauterin, L., Swings, J., and Moore, E. R. B. 1997. Comparison of 16S ribosomal DNA sequences of all Xanthomonas species. Int. J. Syst. Bacteriol. 47:328-335.

23. Hildebrand, D. C., Hendson, M., and Schroth, M. N. 1993. Usefulness of nutritional screening for the identification of Xanthomonas campestris DNA homology groups and pathovars. J. Appl. Bacteriol. 75:447-455.

24. Hildebrand, D. C., Palleroni, N. J., and Schroth, M. N. 1990. Deoxyribonucleic acid relatedness of 24 xanthomonad strains representing 23 Xanthomonas campestris pathovars and Xanthomonas fragariae. J. Appl. Bacteriol. 68:263-269.

25. Janse, J. D., Rossi, M. P., Gorkink, R. F. J., Derks, J. H. J., Swings, J., Janssens, D., and Scortichini, M. 2001. Bacterial leaf blight of strawberry (fragaria (x) ananassa) caused by a pathovar of Xanthomonas arboricola, not similar to Xanthomonas fragariae Kennedy \& King. Description of the causal organism as Xanthomonas arboricola pv. fragariae (pv. nov., comb. nov.). Plant Pathol. 50:653-665.

26. Janssen, P., Coopman, R., Huys, G., Swings, J., Bleeker, M., Vos, P., Zabeau, M., and Kersters, K. 1996. Evaluation of the DNA fingerprinting method AFLP as a new tool in bacterial taxonomy. Microbiology 142:1881-1893.

27. Judd, A. K., Schneider, M., Sadowsky, M. J., and de Bruijn, F. J. 1993. Use of repetitive sequences and the polymerase chain reaction technique to classify genetically related Bradyrhizobium japonicum serocluster 123 strains. Appl. Environ. Microbiol. 59:1702-1708.

28. Lazo, G. R., and Gabriel, D. W. 1987. Conservation of plasmid DNA sequences and pathovar identification of strains of Xanthomonas campestris. Phytopathology 77:448-453.

29. Lazo, G. R., Roffey, R., and Gabriel, D. W. 1987. Pathovars of Xanthomonas campestris are distinguishable by restriction fragment length polymorphism. Int. J. Syst. Bacteriol. 37:214-221.

30. Leyns, F., Decleene, M., Swings, J. G., and Deley, J. 1984. The host range of the genus Xanthomonas. Bot. Rev. 50:308-356.

31. Lipp, R. L., Alvarez, A. M., Benedict, A. A., and Berestecky, J. 1992. Use of monoclonal antibodies and pathogenicity tests to characterize strains of Xanthomonas campestris pv. dieffenbachiae from aroids. Phytopathology 82:677-682.

32. Louws, F. J., and Alvarez, A. M. 2000. Genetic diversity of xanthomonads isolated from aroids as determined by rep-PCR. (Abstr.) Phytopathology 90(suppl.):S47.

33. Louws, F. J., Fulbright, D. W., Stephens, C. T., and de Bruijn, F. J. 1994. Specific genomic fingerprints of phytopathogenic Xanthomonas and Pseudomonas pathovars and strains generated with repetitive sequences and PCR. Appl. Environ. Microbiol. 60:2286-2295.

34. Louws, F. J., Fulbright, D. W., Stephens, C. T., and de Bruijn, F. J. 1995. Differentiation of genomic structure by rep-PCR fingerprinting to rapidly classify Xanthomonas campestris pv. vesicatoria. Phytopathology 85:528536.

35. Louws, F. J., Rademaker, J. L. W., and de Bruijn, F. J. 1999. The three Ds of PCR-based genomic analysis of phytobacteria: Diversity, detection, and disease diagnosis. Annu. Rev. Phytopathol. 37:81-125.

36. Louws, F. J., Ritchie, D. F., and Shoemaker, P. B. 2001. Genetic diversity of selected bacterial populations in North Carolina. Pages 124-127 in: Proc. 10th Int. Conf. Plant Pathogenic Bacteria. S. H. De Boer, ed. Kluwer Academic Publisher, Dordrecht, the Netherlands.

37. Louws, F. J., Schneider, M., and de Bruijn, F. J. 1997. Assessing genetic diversity of microbes using repetitive sequence-based PCR (rep-PCR). Pages 63-94 in: Nucleic Acid Amplification Methods for the Analysis of
Environmental Microbes. G. Toronzos, ed. Technomic Publishing, Lancaster, PA

38. Mkandawire, A. B. C., Mabagala, R. B., Guzman, P., Gepts, P., and Gilbertson, R. L. 2004. Genetic diversity and pathogenic variation of common blight bacteria (Xanthomonas campestris pv. phaseoli and $X$. campestris pv. phaseoli var. fuscans) suggests pathogen coevolution with the common bean. Phytopathology 94:593-603.

39. Moore, E. R. B., Kruger, A. S., Hauben, L., Seal, S. E., Debaere, R., Dewachter, R., Timmis, K. N., and Swings, J. 1997. 16S rRNA gene sequence analyses and inter- and intrageneric relationships of Xanthomonas species and Stenotrophomonas maltophilia. FEMS Microbiol. Lett. 151:145-153.

40. Murata, G. R., and Starr, M. P. 1973. A concept of the genus Xanthomonas and its species in light of segmental homology of deoxyribonucleic acids. Phytopathol. Z. 77:285-323.

41. Norman, D., and Alvarez, A. 1989. A rapid method for presumptive identification of Xanthomonas campestris pv. dieffenbachiae and other xanthomonads. Plant Dis. 73:654-658.

42. Opgenorth, D. C., Smart, C. D., Louws, F. J., de Bruijn, F. J., and Kirkpatrick, B. C. 1996. Identification of Xanthomonas fragariae field isolates by rep-PCR genomic fingerprinting. Plant Dis. 80:868-873.

43. Palleroni, N. J. 1993. Pseudomonas classification-A new case history in the taxonomy of gram-negative bacteria. A. Van Leeuw. J. Microbiol. 64:231-251.

44. Palleroni, N. J., and Bradbury, J. F. 1993. Stenotrophomonas, a new bacterial genus for Xanthomonas maltophilia (Hugh 1980) Swings et al. 1983. Int. J. Syst. Bacteriol. 43:606-609.

45. Palleroni, N. J., Hildebrand, D. C., Schroth, M. N., and Hendson, M. 1993. Deoxyribonucleic-acid relatedness of 21 strains of Xanthomonas species and pathovars. J. Appl. Bacteriol. 75:441-446.

46. Pitcher, D. G., Saunders, N. A., and Owen, R. J. 1989. Rapid extraction of bacterial genomic DNA with guanidium thiocyanate. Lett. Appl. Microbiol. 8:151-156.

47. Pruvost, O., Hartung, J. S., Civerolo, E. L., Dubois, C., and Perrier, X. 1992. Plasmid DNA fingerprints distinguish pathotypes of Xanthomonas campestris pv. citri, the causal agent of citrus bacterial canker disease. Phytopathology 82:485-490.

48. Rademaker, J. L. W., and de Bruijn, F. J. 1997. Characterization and classification of microbes by rep-PCR genomic fingerprinting and computer assisted pattern analysis. Pages 151-171 in: DNA Markers: Protocols, Applications and Overviews. G. Caetano-Anollés and P. M. Gresshoff, eds. John Wiley \& Sons, New York.

49. Rademaker, J. L. W., Hoste, B., Louws, F. J., Kersters, K., Swings, J., Vauterin, L., Vauterin, P., and de Bruijn, F. J. 2000. Comparison of AFLP and rep-PCR genomic fingerprinting with DNA- DNA homology studies: Xanthomonas as a model system. Int. J. Syst. Evol. Microbiol. 50:665677.

50. Rademaker, J. L. W., Louws, F. J., and de Bruijn, F. J. 1998. Characterization of the diversity of ecological important microbes by rep-PCR genomic fingerprinting. Pages 1-26 in: Molecular Microbial Ecology Manual. A. D. L. Akkermans, J. D. van Elsas, and F. J. de Bruijn, eds. Kluwer Academic Publishers, Dordrecht, The Netherlands.

51. Rademaker, J. L. W., Louws, F. J., and de Bruijn, F. J. 1999. Computer assisted pattern analysis of electrophoretic fingerprints and database construction. Pages 1-32 in: Molecular Microbial Ecology Manual. A. D. L. Akkermans, J. D. van Elsas, and F. J. de Bruijn, eds. Kluwer Academic Publishers, Dordrecht, The Netherlands.

52. Restrepo, S., Duque, M., Tohme, J., and Verdier, V. 1999. AFLP fingerprinting: An efficient technique for detecting genetic variation of Xanthomonas axonopodis pv. manihotis. Microbiology (UK) 145:107-114.

53. Sahin, F., Abbasi, P. A., Ivey, M. L. L., Zhang, J., and Miller, S. A. 2003. Diversity among strains of Xanthomonas campestris pv. vitians from lettuce. Phytopathology 93:64-70.

54. Schaad, N. W., Vidaver, A. K., Lacy, G. H., Rudolph, K., and Jones, J. B. 2000. Evaluation of proposed amended names of several pseudomonads and xanthomonads and recommendations. Phytopathology 90:208-213.

55. Smith, J. J., Offord, L. C., Holderness, M., and Saddler, G. S. 1995. Genetic diversity of Burkholderia solanacearum (synonym Pseudomonas solanacearum) race-3 in Kenya. Appl. Environ. Microbiol. 61:4263-4268

56. Smith, J. J., Scott Craig, J. S., Leadbetter, J. R., Bush, G. L., Roberts, D. L., and Fulbright, D. W. 1994. Characterization of random amplified polymorphic DNA (RAPD) products from Xanthomonas and some comments on the use of RAPD products in phylogenetic analysis. Mol. Phylogenet. Evol. 3:135-145.

57. Sneath, P. H. A., and Sokal, R. R. 1973. Numerical Taxonomy. W. H. Freeman \& Co., San Francisco.

58. Stackebrandt, E., Frederiksen, W., Garrity, G. M., Grimont, P. A. D., Kampfer, P., Maiden, M. C. J., Nesme, X., Rossello-Mora, R., Swings, J., Truper, H. G., Vauterin, L., Ward, A. C., and Whitman, W. B. 2002. 
Report of the ad hoc committee for the re-evaluation of the species definition in bacteriology. Int. J. Syst. Evol. Microbiol. 52:10431047.

59. Stackebrandt, E., and Goebel, B. M. 1994. A place for DNA-DNA reassociation and $16 \mathrm{~S}$ ribosomal-RNA sequence analysis in the present species definition in bacteriology. Int. J. Syst. Bacteriol. 44:846-849.

60. Stall, R. E., Beaulieu, C., Egel, D., Hodge, N. C., Leite, R. P., Minsavage, G. V., Bouzar, H., Jones, J. B., Alvarez, A. M., and Benedict, A. A. 1994. Two genetically diverse groups of strains are included in Xanthomonas campestris pv. vesicatoria. Int. J. Syst. Bacteriol. 44:47-53.

61. Sutic, D. 1957. Bakterioze Crvenog Patlid_ana. [Tomato bacteriosis]Posebna Izd. Inst. Zasht. Bilja, Beograd [Spec. Edit. Inst. Plant Prot., Beograd]. Rev. Appl. Mycol. 36:734-735.

62. Swings, J., Vandenmooter, M., Vauterin, L., Hoste, B., Gillis, M., Mew, T. W., and Kersters, K. 1990. Reclassification of the causal agents of bacterial blight (Xanthomonas campestris pv. oryzae) and bacterial leaf streak (Xanthomonas campestris pv. oryzicola) of rice as pathovars of Xanthomonas oryzae (ex ishiyama 1922) sp. nov, nom. rev. Int. J. Syst. Bacteriol. 40:309-311.

63. Tuang, F. N., Rademaker, J. L. W., Alocilja, E. C., Louws, F. J., and de Bruijn, F. J. 1999. Identification of bacterial rep-PCR genomic fingerprints using a backpropagation neural network. FEMS Microbiol. Lett. $177: 249-256$

64. Vandenmooter, M., and Swings, J. 1990. Numerical-analysis of 295 phenotypic features of 266 Xanthomonas strains and related strains and an improved taxonomy of the genus. Int. J. Syst. Bacteriol. 40:348-369.

65. Vauterin, L., Hoste, B., Kersters, K., and Swings, J. 1995. Reclassification of Xanthomonas. Int. J. Syst. Bacteriol. 45:472-489.

66. Vauterin, L., Rademaker, J., and Swings, J. 2000. Synopsis on the taxonomy of the genus Xanthomonas. Phytopathology 90:677-682.

67. Vauterin, L., and Swings, J. 1997. Are classification and phytopathological diversity compatible in Xanthomonas? J. Ind. Microbiol. Biotechnol. 19:77-82.

68. Vauterin, L., Swings, J., and Kersters, K. 1991. Grouping of Xanthomonas campestris pathovars by SDS-PAGE of proteins. J. Gen. Microbiol. 137:1677-1687.

69. Vauterin, L., Swings, J., Kersters, K., Gillis, M., Mew, T. W., Schroth, M. N., Palleroni, N. J., Hildebrand, D. C., Stead, D. E., Civerolo, E. L., Hayward, A. C., Maraite, H., Stall, R. E., Vidaver, A. K., and Bradbury, J. F. 1990. Towards an improved taxonomy of Xanthomonas. Int. J. Syst. Bacteriol. 40:312-316.

70. Vauterin, L., and Vauterin, P. 1992. Computer aided objective comparison of electrophoretic pattern for grouping and identification of micro- organisms. Eur. Microbiol. 1:37-41.

71. Vauterin, L., Yang, P., Alvarez, A., Takikawa, Y., Roth, D. A., Vidaver, A. K., Stall, R. E., Kersters, K., and Swings, J. 1996. Identification of nonpathogenic Xanthomonas strains associated with plants. Syst. Appl. Microbiol. 19:96-105.

72. Vauterin, L., Yang, P., Hoste, B., Pot, B., Swings, J., and Kersters, K. 1992. Taxonomy of xanthomonads from cereals and grasses based on SDS-PAGE of proteins, fatty-acid analysis and DNA hybridization. J. Gen. Microbiol. 138:1467-1477.

73. Vauterin, L., Yang, P., Hoste, B., Vancanneyt, M., Civerolo, E. L., Swings, J., and Kersters, K. 1991. Differentiation of Xanthomonas campestris pv. citri strains by sodium dodecyl sulfate-polyacrylamide gel-electrophoresis of proteins, fatty-acid analysis, and DNA-DNA hybridization. Int. J. Syst. Bacteriol. 41:535-542.

74. Vauterin, L., Yang, P., and Swings, J. 1996. Utilization of fatty acid methyl esters for the differentiation of new Xanthomonas species. Int. J. Syst. Bacteriol. 46:298-304.

75. Versalovic, J., Koeuth, T., and Lupski, J. R. 1991. Distribution of repetitive DNA-sequences in eubacteria and application to fingerprinting of bacterial genomes. Nucleic Acids Res. 19:6823-6831.

76. Versalovic, J., Schneider, M., de Bruijn, F. J., and Lupski, J. R. 1994. Genomic fingerprinting of bacteria using repetitive sequence-based polymerase chain reaction. Methods Mol. Cell. Biol. 5:25-40.

77. Vinuesa, P., Rademaker, J. L. W., de Bruijn, F. J., and Werner, D. 1998. Genotypic characterization of Bradyrhizobium strains nodulating endemic woody legumes of the Canary Islands by PCR-restriction fragment length polymorphism analysis of genes encoding 16S rRNA (16S rDNA) and $16 \mathrm{~S}-23 \mathrm{~S}$ rDNA intergenic spacers, repetitive extragenic palindromic PCR genomic fingerprinting, and partial 16S rDNA sequencing. Appl. Environ. Microbiol. 64:2096-2104.

78. Wayne, L. G., Brenner, D. J., Colwell, R. R., Grimont, P. A. D., Kandler, O., Krichevsky, M. I., Moore, L. H., Moore, W. E. C., Murray, R. G. E., Stackebrandt, E., Starr, M. P., and Truper, H. G. 1987. Report of the adhoc-committee on reconciliation of approaches to bacterial systematics. Int. J. Syst. Bacteriol. 37:463-464.

79. Woese, C. R. 1987. Bacterial evolution. Microbiol. Rev. 51:221-271.

80. Yang, P., Vauterin, L., Vancanneyt, M., Swings, J., and Kersters, K. 1993. Application of fatty-acid methyl-esters for the taxonomic analysis of the genus Xanthomonas. Syst. Appl. Microbiol. 16:47-71.

81. Young, J. M., Bull, C. T., De Boer, S. H., Firrao, G., Gardan, L., Saddler, G. E., Stead, D. E., and Takikawa, Y. 2001. Classification, nomenclature, and plant pathogenic bacteria-A clarification. Phytopathology 91:617620 . 